RPP-48379, Rev. 0

\title{
Technology Readiness Evaluation for Aluminum Removal and Sodium Hydroxide Regeneration from Hanford Tank Waste by Lithium Hydrotalcite Precipitation
}

\author{
Harold Massie (AREVA Federal Services LLC) \\ Washington River Protection Solutions \\ Richland, WA 99352 \\ U.S. Department of Energy Contract DE-AC27-08RV14800

$\begin{array}{llll}\text { EDT/ECN: } & \text { DRF } & \text { UC: } \\ \text { Cost Center: } & \text { 2GB00 } & \text { Charge Code: } 200700 \\ \text { B\&R Code: } & & \text { Total Pages: } 47\end{array}$

Key Words: Technology Readiness Evaluation, TRE, Technology Readiness Assessment, TRA, Technology Maturation Plan, TMP, Lithium Hydrotalcite, LiHT, Hanford, Single-Shell Tank, SST, Double-Shell Tank, DST, Critical Technology Element, CTE, Technology Readiness Level, TRL, tank waste, aluminum, precipitation.

Abstract: A Technology Readiness Evaluation (TRE) performed by AREVA Federal Services, LLC (AFS) for Washington River Protection Solutions, LLC (WRPS) shows the lithium hydrotalcite (LiHT) process invented and patented (pending) by AFS has reached an overall Technology Readiness Level (TRL) of 3 . The LiHT process removes aluminum and regenerates sodium hydroxide. The evaluation used test results obtained with a 2-L laboratory-scale system to validate the process and its critical technology elements (CTEs) on Hanford tank waste simulants. The testing included detailed definition and evaluation for parameters of interest and validation by comparison to analytical predictions and data quality objectives for critical subsystems. The results of the TRE would support the development of strategies to further mature the design and implementation of the LiHT process as a supplemental pretreatment option for Hanford tank waste.

TRADEMARK DISCLAIMER. Reference herein to any specific commercial product, process, or service by trade name, trademark, manufacturer, or otherwise, does not necessarily constitute or imply its endorsement, recommendation, or favoring by the United States Government or any agency thereof or its contractors or subcontractors.

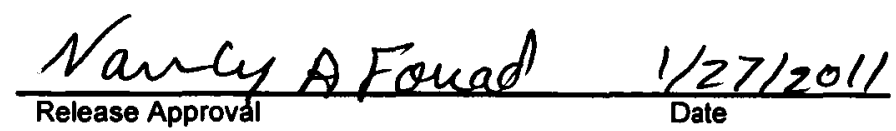

Approved For Public Release

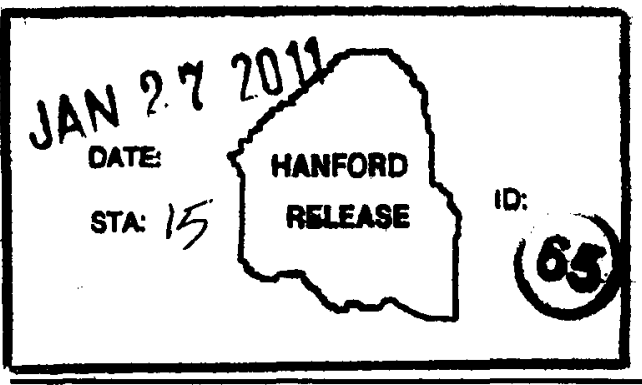

Release Stamp 


\section{Technology Readiness Evaluation for Aluminum Removal and Sodium Hydroxide Regeneration from Hanford Tank Waste by Lithium Hydrotalcite Precipitation}

Harold Massie

AREVA Federal Services LLC

Date Published

December 2010

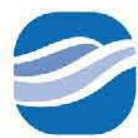

\section{washingtonriver}

protectionsolutions

P.O. Box 850

Richland, Washington 99352

Prepared for the U.S. Department of Energy

Assistant Secretary for Environmental Management

Contractor for the U.S. Department of Energy

Office of River Protection under Contract DE-AC27-08RV14800 
RPP-48379, Rev. 0

\begin{abstract}
A Technology Readiness Evaluation (TRE) performed by AREVA Federal Services, LLC (AFS) for Washington River Protection Solutions, LLC (WRPS) shows the lithium hydrotalcite (LiHT) process invented and patented (pending) by AFS has reached an overall Technology Readiness Level (TRL) of 3. The LiHT process removes aluminum and regenerates sodium hydroxide. The evaluation used test results obtained with a 2-L laboratory-scale system to validate the process and its critical technology elements (CTEs) on Hanford tank waste simulants. The testing included detailed definition and evaluation for parameters of interest and validation by comparison to analytical predictions and data quality objectives for critical subsystems. The results of the TRE would support the development of strategies to further mature the design and implementation of the LiHT process as a supplemental pretreatment option for Hanford tank waste.
\end{abstract}

\title{
KEY WORDS
}

Technology Readiness Evaluation, TRE, Technology Readiness Assessment, TRA, Technology Maturation Plan, TMP, Lithium Hydrotalcite, LiHT, Hanford, Single-Shell Tank, SST, Double-Shell Tank, DST, Critical Technology Element, CTE, Technology Readiness Level, TRL, tank waste, aluminum, precipitation. 
RPP-48379, Rev. 0

\section{EXECUTIVE SUMMARY}

Washington River Protection Solutions, LLC (WRPS) is evaluating a lithium hydrotalcite (LiHT) process invented and patented (pending) by AREVA Federal Services, LLC (AFS) as a supplemental pretreatment option for Hanford tank waste as part of the River Protection Plan (RPP) mission.

In support of the WRPS effort, AFS has performed a Technology Readiness Evaluation (TRE) of the LiHT process for aluminum removal and sodium hydroxide regeneration from Hanford tank waste. The TRE was performed in a manner that would allow its results to provide input to technology maturation planning as outlined in the DOE EM Technology Readiness Assessment (TRA)/Technology Maturation Plan (TMP) Process Guide and the DOE Technology Readiness Assessment Guide.

The TRE was based on a process block flow diagram, process description, process flowsheets, and the results of 2-liter laboratory-scale validation tests. It identified six critical technology elements (CTEs) of the LiHT process, five of which were evaluated for and were found to have achieved a technology readiness level (TRL) of 3 . The sixth CTE identified operability issues that are beyond the scope of TRL 3, but will need to be considered in later stages of system design and maturity development.

It was determined that the LiHT process has reached an overall TRL of 3, which means the research, development, and testing have validated the process and its CTEs in laboratory-scale testing on Hanford tank waste simulants. The TRL 3 testing included a detailed definition and evaluation for parameters of interest and validation by comparison of test results to analytical predictions and data quality objectives for critical subsystems.

The results of the TRE would support the development of strategies to further mature the LiHT process. Specific actions for maturing the CTEs from TRL 4 to TRL 6 would be detailed in the TMP. 


\section{TABLE OF CONTENTS}

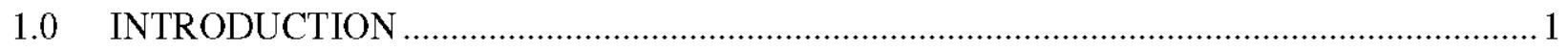

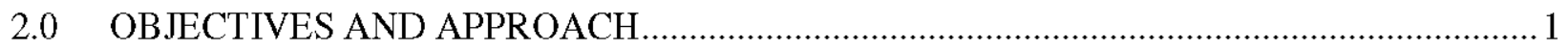

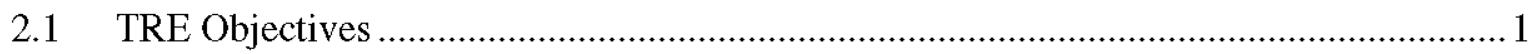

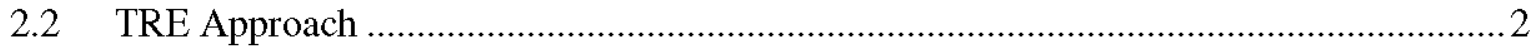

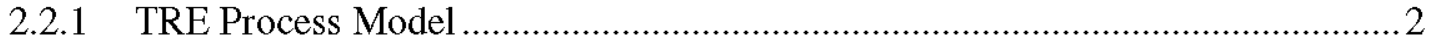

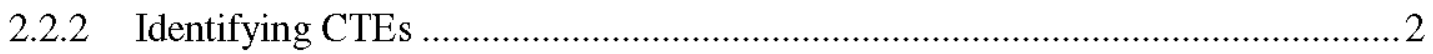

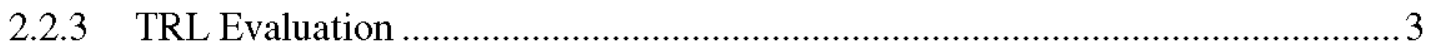

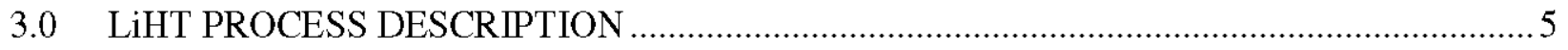

3.1 Technology Need for the LiHT Process at Hanford …………………….......................5

3.2 Technology Heritage of the LiHT Process.....................................................................

3.3 Main Functions of the LiHT Processing System ……………………….....................

3.4 Ancillary Processes ..........................................................................................

3.5 Summary of Hanford Waste Treatment with the LiHT Process ………………………....

3.6 Bench Scale Validation Tests of the LiHT Process ..........................................................

4.0 IDENTIFICATION OF CRITICAL TECHNOLOGY ELEMENTS ....................................... 10

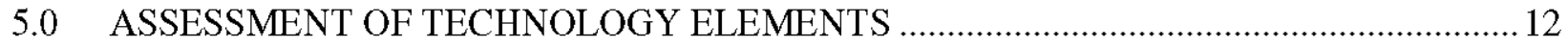

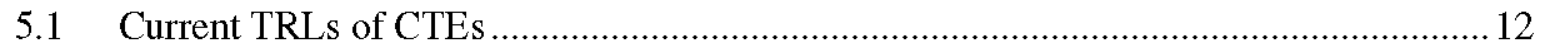

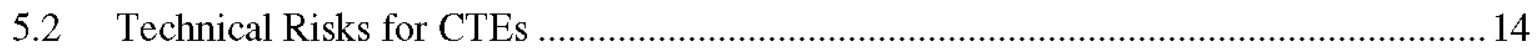

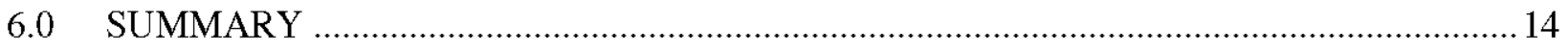

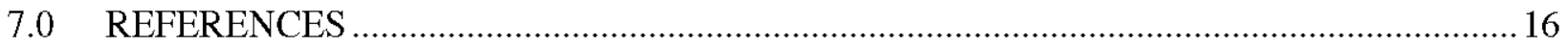

\section{TABLE OF APPENDICES}

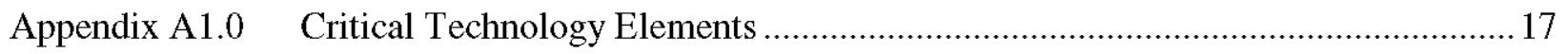

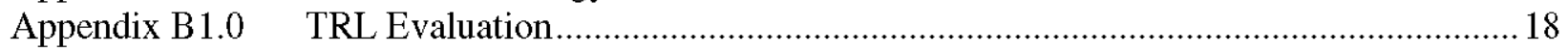

TABLE OF FIGURES

Figure 1: Schematic of DOE EM Technology Readiness Levels ........................................................

\section{TABLE OF TABLES}

Table 1: DOE EM Technology Readiness Levels . 
RPP-48379, Rev. 0

\section{LIST OF TERMS}

\section{Abbreviations and Acronyms}

AFS

CSL

CTE

DST

DOE

EM

ESP

ETF

FC

FY

HLW

ILAW

LAW

LiHT

MSE

ORP

PMP

RPP

STP

SST

TMP

TRA

TRE

TRL

WRPS

WTP
AREVA Federal Services LLC

Continuous Sludge Leaching

Critical Technology Element

Double Shell Tank

U.S. Department of Energy

Environmental Management

Environmental Simulation Program

Effluent Treatment Facility

Fractional Crystallization

Fiscal Year

High Level Waste

Immobilized Low Activity Waste

Low Activity Waste

Lithium Hydrotalcite Precipitation

Mixed Solvent Electrolyte

Office of River Protection

Project Management Plan

River Protection Plan

Sludge Treatment Project

Single Shell Tank

Technology Maturation Plan

Technology Readiness Assessment

Technology Readiness Evaluation

Technology Readiness Level

Washington River Protection Solutions, LLC

Waste Treatment and Immobilization Plant 
RPP-48379, Rev. 0

\section{$1.0 \quad$ INTRODUCTION}

As a prime contractor to the U.S. DOE, Washington River Protection Solutions, LLC (WRPS) is preparing long term strategic planning options and evaluations to accomplish the mission of the River Protection Plan (RPP) including evaluation and development of supplemental pretreatment options for Hanford tank waste. A lithium hydrotalcite precipitation (LiHT) process is one option being evaluated.

AREVA Federal Services, LLC (AFS) invented and patented ${ }^{1}$ (pending) the LiHT Process, and is supporting WRPS efforts to determine what is needed to mature this technology through the different steps of development towards its potential integration into the Hanford tank waste treatment process.

This document provides a preliminary Technology Readiness Evaluation (TRE) of the LiHT process for aluminum removal and sodium hydroxide regeneration from Hanford tank waste. This TRE is performed in a manner that would allow its results to provide input to technology maturation planning as discussed in the U.S. Department of Energy, Office of Environment Management, Technology Readiness Assessment (TRA) / Technology Maturation Plan (TMP) Process Guide, 2008 and the U.S. Department of Energy, Office of Management, Technology Readiness Assessment Guide, DOE G413.3-4, October 2009.

This TRE was mostly based on a process block flow diagram and process flowsheets in RPP-48377, Aluminum Removal and Sodium Hydroxide Regeneration from Hanford Waste by Lithium Hydrotalcite Precipitation, Process Model Flowsheet, AREVA, 2010 and information for the laboratory scale validation tests from RPP-PLAN-48088, Data Quality Objectives for Lithium Hydrotalcite Process Validation AREVA, 2010; RPP-43328, Test Program for Aluminum Removal and Sodium Hydroxide Regeneration from Hanford Waste by Lithium Hydrotalcite Precipitation, AREVA, 2010; and RPP-RPT-48380, Aluminum Removal and Sodium Regeneration from Hanford Waste by Lithium Hydrotalcite Precipitation; Laboratory Scale Validation on Waste Simulants, Test Report, AREVA, 2010.

\subsection{OBJECTIVES AND APPROACH}

\subsection{TRE Objectives}

The objectives of this TRE are to identify the critical technology elements (CTEs) of the LiHT process, assess the Technology Readiness Level (TRL) of the CTEs, as evidenced by testing and modeling, and identify technology maturity issues that need to be addressed for the technology elements to advance to the next level. This TRE is warranted as part of a larger ongoing discussion and evaluation of technical risks and mitigations. A formal report equivalent to an independent assessment of the TRA status as described in the DOE guides is not the focus of this TRE.

The TRE does the following:

- Identify maturity gaps in:

- Testing.

- Demonstration and knowledge of a technology's current readiness level.

- Steps needed to reach higher levels of readiness.

\footnotetext{
${ }^{1}$ PCT International Application PCT/US2008/076589
} 
- Identify technology elements that need more management attention or more resources for technology development.

- Spot immature or unproven technology elements that might increase project risk.

\subsection{TRE Approach}

\subsubsection{TRE Process Model}

This TRE follows the U.S. Department of Energy, Office of Environment Management, Technology Readiness Assessment (TRA)/ Technology Maturation Plan (TMP) Process Guide, 2008, which has two sequential steps:

- Identify the CTEs

- Assess the TRL of each CTE

\subsubsection{Identifying CTEs}

The following statement from the U.S. Department of Energy, Office of Environment Management, Technology Readiness Assessment (TRA) / Technology Maturation Plan (TMP) Process Guide defines a CTE:

A technology element is "critical" if the system being acquired depends on this technology element to meet operational requirements (with acceptable development cost and schedule and with acceptable production and operation costs) and if the technology element or its application is either new or novel. Said another way, an element that is new or novel or being used in a new or novel way is critical if it is necessary to achieve the successful development of a system, its acquisition, or its operational utility.

The CTE identification applies two sets of criteria from Appendix E of the U.S. Department of Energy, Office of Environment Management, Technology Readiness Assessment (TRA) / Technology Maturation Plan (TMP) Process Guide, 2008 to technology elements shown in the LiHT process block diagram, process description, and flowsheets RPP-48377 and the data quality objectives RPPPLAN-48088. These references and others (e.g., RPP-43328, RPP-PLAN-48085, RPP-48376, RPP48089, RPP-PLAN-48090, RPP-PLAN-48091, RPP-PLAN-48381, LAB-RPT-10-00003 Rev. 0) were used to identify technology elements that are critical to the successful operation of the LiHT process and that are new or novel applications of technology. 
To be a CTE candidate, the answer to at least one of the following questions is positive:

\section{First Set -- Criticality to Program Criteria:}

- Does the technology directly impact a functional requirement of the process or facility?

- Do the limitations in the understanding of the technology result in a potential schedule risk; i.e., the technology may not be ready for insertion when required?

- Do limitations in the understanding of the technology result in a potential cost risk; i.e., the technology may cause significant cost overruns?

- Do limitations in the understanding of the technology impact the safety of the design?

- Are there uncertainties in the definition of the end state requirements for this technology?

Additionally, for a technology to be critical, the answer to at least one of the following questions is positive:

\section{$\underline{\text { Second Set -- New or Novel Criteria: }}$}

- Is the technology new or novel?

- Is the technology modified?

- Does the technology have potential hazards that need to be assessed?

- Has the technology been repackaged so that a new relevant environment is realized?

- Is the technology expected to operate in an environment and/or achieve a performance beyond its original design intention or demonstrated capability?

\subsubsection{TRL Evaluation}

The TRL indicates the maturity of a CTE as defined in Table 1 and illustrated in Figure 1 . The readiness scale ranges from TRL 1 (basic principles observed) through TRL 9 (total system used successfully in project operations). The TRL evaluation for this TRE used TRL evaluation criteria and questionnaires from the Technology Readiness Assessment Guide, DOE G413.3-4. 
Table 1: DOE EM Technology Readiness Levels

\begin{tabular}{|c|c|c|c|}
\hline $\begin{array}{l}\text { Relative Level of } \\
\text { Technology } \\
\text { Development }\end{array}$ & $\begin{array}{l}\text { Technology } \\
\text { Readiness } \\
\text { Level }\end{array}$ & TRL Definition & TRL Overview \\
\hline $\begin{array}{l}\text { System } \\
\text { Operations }\end{array}$ & TRL 9 & $\begin{array}{l}\text { Actual system operated } \\
\text { over the full range of } \\
\text { expected conditions. }\end{array}$ & $\begin{array}{l}\text { Operate the technology in final form implementation } \\
\text { under the full range of waste and operating } \\
\text { conditions. Full operational capability. }\end{array}$ \\
\hline \multirow[t]{2}{*}{$\begin{array}{l}\text { System } \\
\text { Commissioning }\end{array}$} & TRL 8 & $\begin{array}{l}\text { Actual system } \\
\text { completed and qualified } \\
\text { through test and } \\
\text { demonstration. }\end{array}$ & $\begin{array}{l}\text { Prove technology works under expected hot waste } \\
\text { conditions. End of system development. Initial } \\
\text { operational capability. }\end{array}$ \\
\hline & TRL 7 & $\begin{array}{l}\text { Full-scale, similar } \\
\text { (prototypical) system } \\
\text { demonstrated in } \\
\text { relevant environment. }\end{array}$ & $\begin{array}{l}\text { Demonstrate system prototype in a relevant } \\
\text { environment including the full range of simulants. } \\
\text { Final design complete. }\end{array}$ \\
\hline \multirow[t]{2}{*}{$\begin{array}{l}\text { Technology } \\
\text { Demonstration }\end{array}$} & TRL 6 & $\begin{array}{l}\text { Engineering/pilot-scale } \\
\text { (1/10 to full scale), } \\
\text { similar (prototypical) } \\
\text { system validation in } \\
\text { relevant environment }\end{array}$ & $\begin{array}{l}\text { Engineering/pilot scale demonstration in relevant } \\
\text { environment including the full range of simulants. } \\
\text { TRL } 6 \text { begins true engineering development and } \\
\text { results in a prototype capable of performing all } \\
\text { operations of a functional system. }\end{array}$ \\
\hline & TRL 5 & $\begin{array}{l}\text { Laboratory scale (less } \\
\text { than } 1 / 10 \text { of full scale), } \\
\text { similar system } \\
\text { validation in relevant } \\
\text { environment }\end{array}$ & $\begin{array}{l}\text { Basic technology integration to ensure operational } \\
\text { compatibility. Testing with the full range of } \\
\text { simulants and small-scale actual waste. Testing of } \\
\text { high-fidelity, laboratory scale system in a simulated } \\
\text { environment with a range of simulants and actual }\end{array}$ \\
\hline \multirow[t]{2}{*}{$\begin{array}{l}\text { Technology } \\
\text { Development }\end{array}$} & & & $\begin{array}{l}\text { waste. Major step up in the fidelity of the system } \\
\text { and the environment to the actual application. } \\
\text { System tested is almost prototypical. }\end{array}$ \\
\hline & TRL 4 & $\begin{array}{l}\text { Component and/or } \\
\text { system validation in } \\
\text { laboratory environment }\end{array}$ & $\begin{array}{l}\text { TRL } 4 \text { is the first step in establishing that the } \\
\text { technological components will work together in an } \\
\text { integrated system. First step in establishing system } \\
\text { compatibility. Testing with a range of simulants and } \\
\text { small scale actual tests on actual waste. Supporting } \\
\text { information includes the results of integrated } \\
\text { experiments and estimates of how the experimental } \\
\text { components and experimental test results differ from } \\
\text { expected system performance goals. TRL } 4-6 \\
\text { represent the bridge from scientific research to } \\
\text { engineering. }\end{array}$ \\
\hline \multirow[t]{2}{*}{$\begin{array}{l}\text { Research to } \\
\text { Prove Feasibility }\end{array}$} & TRL 3 & $\begin{array}{l}\text { Analytical and } \\
\text { experimental critical } \\
\text { function and/or } \\
\text { characteristic proof of } \\
\text { concept }\end{array}$ & $\begin{array}{l}\text { Initiate active research and development. Analytical } \\
\text { and laboratory scale validation studies. Validate } \\
\text { system components. Determine parameters of } \\
\text { interest and compare analytical predictions for } \\
\text { critical subsystems. }\end{array}$ \\
\hline & TRL 2 & Technology concept & Develop practical applications of basic principles. \\
\hline \multirow[t]{2}{*}{$\begin{array}{l}\text { Basic Technology } \\
\text { Research }\end{array}$} & & $\begin{array}{l}\text { and/or application } \\
\text { formulated }\end{array}$ & $\begin{array}{l}\text { Assemble publications and corroborative work. } \\
\text { Move from pure to applied research. }\end{array}$ \\
\hline & TRL 1 & $\begin{array}{l}\text { Basic principles } \\
\text { observed and reported }\end{array}$ & $\begin{array}{l}\text { Translate scientific research principles to applied } \\
\text { development. Paper studies of basic properties of } \\
\text { technology and observations. }\end{array}$ \\
\hline
\end{tabular}


Figure 1: Schematic of DOE EM Technology Readiness Levels

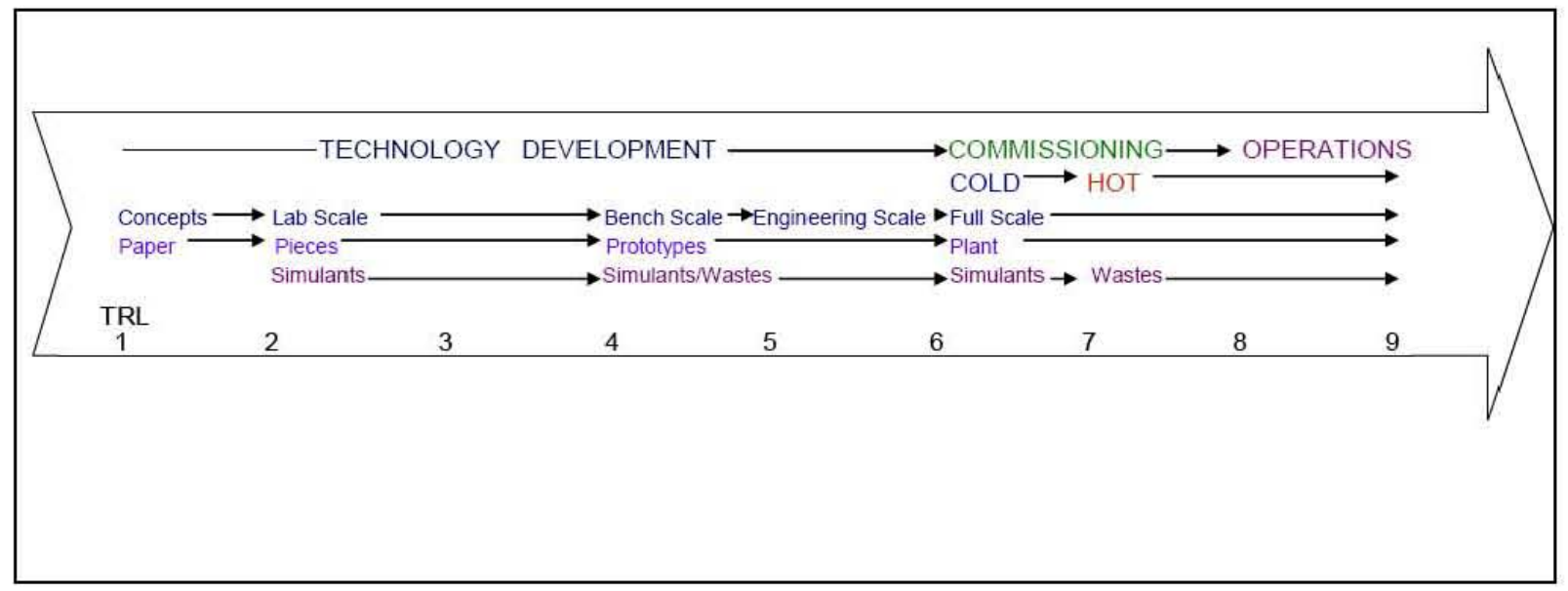

\subsection{LIHT PROCESS DESCRIPTION}

\subsection{Technology Need for the LiHT Process at Hanford}

The DOE Office of River Protection (ORP) is constructing a Waste Treatment and Immobilization Plant (WTP) for the treatment and vitrification of $\sim 57$ million gallons of liquid waste and sludge stored in underground single-shell tanks (SSTs) and double-shell tanks (DSTs) at the Hanford Site north of Richland, Washington. The Hanford sludge waste contains approximately 8,710 MT of aluminum, a significant fraction of the non-radioactive components of the waste.

Under current waste retrieval projects and WTP flowsheets, sludge leaching using $\mathrm{NaOH}$ is the baseline process for solubilizing the aluminum in the tank waste to obtain sodium aluminate, a liquid waste form that can be processed at the WTP. However, it is expected that the additional amount of sodium, in the form of $\mathrm{NaOH}$ that would be required would double the total sodium load of the Hanford waste to the WTP, double the volume of low activity waste (LAW), and significantly impact the waste processing schedule over the baseline. The increased sodium inventory would lead to proportional increases in WTP processing time and operational cost, and in the volumes of immobilized low activity waste (ILAW) glass produced for storage or disposal. Removal of aluminum from the tank waste upstream of or prior to WTP operations would be critically important in helping to minimize the waste processing time and operational cost of the WTP and in reducing the amount of ILAW glass produced by the WTP.

WRPS is preparing long-term strategic planning options and evaluations to accomplish the RPP mission. The LiHT process, invented and patented (pending), PCT International Application PCT/US2008/076589, AREVA, 2008 by AFS, is being evaluated under the "Lithium Hydrotalcite Pretreatment Planning" project. The LiHT process would both remove aluminum and its negative operational consequences from the waste process stream and would produce, as a by-product, recyclable sodium hydroxide that can be used to dissolve aluminum sludge in tank waste.

The proposed LiHT process uses lithium hydroxide as an additive to the solubilized tank sludge containing aqueous sodium aluminate to precipitate LiHT, which may be separated by filtration and decontaminated with water washing. After drying, the LiHT would be available for use as a WTP glass former or for immobilization and disposal in another approved waste form. 
RPP-48379, Rev. 0

\subsection{Technology Heritage of the LiHT Process}

In 2007, AFS contracted the Chemical Engineering Department of the Georgia Institute of Technology (Georgia Tech) to conduct a two-phase laboratory program of bench-scale experiments using non-radioactive Hanford waste simulants. These experiments, described in Section 2.2 of RPP-PLAN-48085, demonstrated the viability of the LiHT process as summarized in RPP-48376. The analytical results of the Georgia Tech experiments are consistent with reports in the literature and with the thermodynamic models of the LiHT process.

The LiHT process is based on the Bayer Process used by the aluminum industry to extract aluminum oxide from bauxite ore by treating the ore with sodium hydroxide. The insoluble impurities are separated from the sodium aluminate solution, which is then cooled. The resulting precipitate is filtered and processed to recover aluminum.

The separation and removal of the sodium aluminate from Hanford tank wastes by using the LiHT process is quasi-analogous to the Bayer Process in that both the ore and the aluminum in the tank wastes require leaching with sodium hydroxide to solubilize the aluminum so that it can be separated from the mother liquor. Theoretically, the Bayer Process could be used to remove aluminum and regenerate sodium hydroxide from the tank waste leachate. However, laboratory experiments using DST waste simulants have shown, similar to industry experience, that a strict application of the Bayer Process is very slow ( $\sim 5$ days) with a per-pass yield of $\sim 50 \%$. This level of process yield would require crystal seeding and a high recycle rate to obtain optimum yield.

The process modification invented (patent pending) by AFS overcomes the two main disadvantages of the application of the Bayer Process for aluminum removal from tank waste, e.g., the slow pace and the per-pass yield of the reaction. This alternative method is the LiHT process, which is similar to processes used in industry to produce low-cost synthetic hydrotalcites (Duan, X. and D.G. Evans, Layered Double Hydroxides (Structure and Bonding), ISSN 0081-5993).

\subsection{Main Functions of the LiHT Processing System}

The LiHT block diagram and process flowsheets (RPP-48377) show interfaces for the upstream and downstream waste treatment processes and associated systems and portray the LiHT process and its technology elements as part of an integrated LiHT Processing System, whose main functions are:

- Receive filtered feed from in situ tank leaching or from an ex situ continuous sludge leaching process.

- Precipitate LiHT solid from Hanford tank waste.

- Separate by filtration the solid LiHT from the mother liquor containing regenerated sodium hydroxide.

- Decontaminate the separated hydrotalcite with wash water.

- Make the decontaminated hydrotalcite available for LAW immobilization or disposal as another approved waste form. Optionally, the hydrotalcite could be dried and stored for later use as a LAW glass former. 


\subsection{Ancillary Processes}

The following ancillary processes will be performed outside the LiHT process:

- Concentrate and recycle the mother liquor containing regenerated sodium hydroxide to the tank farms for further aluminum leaching.

- Distill by evaporation and recycle spent wash water and, optionally, crystallize low-solubility sodium salts from the filtrates and wash water.

- Immobilize the decontaminated (washed) solids.

\subsection{Summary of Hanford Waste Treatment with the LiHT Process}

The objectives of the LiHT process described in RPP-48377 are to remove aluminum from Hanford sodium hydroxide leached tank waste as a LiHT solid and to regenerate sodium hydroxide to be recycled back to leach aluminum sludge in tank waste. The following discussion briefly summarizes the process flow and the treatment of Hanford SST and DST waste with the LiHT Process:

The sludge, high in aluminum, and the supernatant, high in aluminum and sodium hydroxide, are retrieved from the Hanford underground tanks and then heat leached by using native and recycled sodium hydroxide. Saltcake brines, which are low in sodium hydroxide and aluminum, bypass the LiHT process and are fed directly to the WTP. Residual sludge that is low in aluminum is then fed to the WTP. The resulting LiHT precipitate containing the aluminum is precipitated, filtered, washed, dried, and transferred to an immobilization unit.

Filtrate from the LiHT process contains regenerated sodium hydroxide and is transferred to an evaporation unit. This unit concentrates the sodium hydroxide stream, which is recycled to leach aluminum sludge. Condensate from the evaporation provides wash water, which is then recycled back to the LiHT decontamination system. Excess caustic is returned to waste tanks or purged to the WTP. Excess distilled water is exported to the Effluent Treatment Facility (ETF).

\subsection{Bench Scale Validation Tests of the LiHT Process}

This section summarizes laboratory scale preliminary and validation tests, including the experimental basis for the Georgia Tech tests, the tests performed by WRPS, and the AREVA 2010 validation tests. The results of these tests and the experimental basis are essential to showing the LiHT technology has reached TRL 3 .

Georgia Tech Bench-Scale Tests

A two-phase laboratory program was conducted by AFS at Georgia Tech to demonstrate the viability of the LiHT process (RPP-48376-000).

Phase 1 experiments tested the temperature and $\mathrm{pH}$ ranges of the LiHT process. One-liter benchscale experiments demonstrated that high LiHT yield $(>93 \%)$ was obtained at high temperature $\left(100^{\circ} \mathrm{C}\right)$ and high $\mathrm{pH}(>14)$ and that cooling and/or carbonation did not enhance yield. The results of the Phase 1 experiments showed the process can be performed directly using concentrated $\mathrm{NaOH}$ waste without dilution or partial neutralization and at elevated temperature to maximize the production of LiHT and therefore the aluminum yield. Also, the presence of carbonate in the tank 
waste did not limit the amount of hydrotalcite precipitated. The results of the experiments showed that other anions (e.g., $\mathrm{NO}_{3}{ }^{-}$and $\mathrm{NO}_{2}{ }^{-}$) may substitute in a carbonate depleted system.

The Phase 2 experiments tested the sensitivity of the $\mathrm{Li} / \mathrm{Al}$ mole ratio, the lithium reagent $\left(\mathrm{LiNO}_{3}\right.$ and $\mathrm{LiOH}$ were tested), the reaction period, solid/liquid separability (by filtration), and the amount of wash water needed for decontamination of the hydrotalcite filter cake. The results of the experiments concur with the literature reports in Duan, X. and D.G. Evans, Layered Double Hydroxides (Structure and Bonding), ISSN 0081-5993 and thermodynamic modeling of the LiHT process using the Environmental Simulation Program (ESP Version 8.1, OLI Systems, Inc.). The LiHT produced in the Phase 2 experiments was microscopically imaged and was observed to consist of $\sim 50 \mu \mathrm{m}$ particles with a narrow size distribution and which were easily separated from the simulated waste solution. In addition, Phase 2 testing using a simulant that contained a non-radioactive cesium surrogate showed that cesium was removed from the LiHT precipitate by water washing. A cesium decontamination factor of $>2,000$ was determined from these experiments when the Cs-spiked filter cake was washed with deionized water. The Phase 2 experiments also confirmed that sodium hydroxide was regenerated by the LiHT Process reaction.

WRPS Bench-Scale Tests

In the WRPS tests (LAB-RPT-10-00003, Revision 0), the 222-S Laboratory at the Hanford Site was tasked to verify the precipitation of aluminum using lithium hydroxide as proposed by AFS. The results are as follows:

- A process for removing aluminum from tank waste simulants by adding lithium and precipitating Li-Al-dihydroxide was verified. The tests involved DST and SST simulant. In the case of DST simulant, the product was the anticipated LiHT. In the case of the SST simulant, the product formed was primarily $\mathrm{Li}$-phosphate. Adding excess $\mathrm{Li}$ to the solution did result in the formation of LiHT.

- The LiHT from the DST supernate was an easily filterable solid. After four water washes the filter cake was a fluffy white material made of $<100 \mu \mathrm{m}$ particles made of smaller spheres. These spheres were agglomerates of $\sim 5 \mu \mathrm{m}$ diameter platelets with $<1 \mu \mathrm{m}$ thickness. Chemical and mineralogical analyses of the filtrate, filter cake, and wash waters indicate a removal of $90+w t \%$ of the dissolved $\mathrm{Al}$ for the DST simulant.

- For the SST simulant, the main competing reaction to the formation of LiHT appeared to be the formation of Li-phosphate. In the case of the DST simulant, phosphorous co-precipitated with the hydrotalcite. The results implied there was the added benefit of the removal of phosphorous along with aluminum in the pre-treatment part of the WTP.

- As a result of the testing, it was recommended that a serious effort be made toward process parameter optimization with the major issues to be addressed including the dependency of the reaction yield on the solution chemistry as well as residence times, temperatures, and an understanding of particle growth. 
Additional two-liter bench-scale tests, conducted in 2010 by AREVA and described in RPP-43328 and RPP-RPT-48380, demonstrated the following:

- LiHT Process Design.

This CTE includes the lab-scale equipment, the LiHT process flow, and the test protocols for demonstrating the LiHT process for TRL 3 . The test demonstrated a process flow that included the following: (1) deliver waste simulant to the process, (2) precipitate LiHT solid from the simulant(s), (3) separate solid LiHT from the mother liquor containing $\mathrm{NaOH}$ by filtration, and (4) decontaminate the separated hydrotalcite with wash water. The testing used a commercial laboratory reactor system.

- Aluminum Precipitation from DST and SST Simulants.

The testing used SST and DST non-radioactive simulants to represent the chemical and physical properties of actual supernatant and sludge wastes stored in the Hanford SSTs and DSTs. The simulants were prepared using chemical formulation recipes in RPP-PLAN-48090 as a basis. The testing simulated this CTE by adding $\mathrm{LiOH}$ solution via a small peristaltic pump to the reactor vessel containing simulant. The process was manually performed by controlling the temperature and agitating the solution per prescribed testing protocols. The testing demonstrated the LiHT process removed more than $85 \%$ of the soluble $\mathrm{Al}$ from Hanford SST and DST waste simulants.

- Filtering of Precipitated LiHT Solids.

The bottom outlet of the reactor was opened to allow the slurry to drain into filter paper placed in a Büchner funnel. Chemical analysis was performed on samples of the filtrate and wet filter cake. The testing demonstrated the solids produced from the reaction can be readily filtered under normal laboratory conditions.

- Decontamination of LiHT Solids.

The testing examined decontamination as a function of the number of washes. The reactor contents were manually filtered, the filter cake scraped from the funnel into a beaker, and the product filter cake manually washed. The filter cake was then re-pulped in wash water and the filter cake was sampled and analyzed after each wash increment. The extent of cesium decontamination was calculated from the results. The testing demonstrated the ability of the $\mathrm{LiHT}$ process to generate solids that can be washed sufficiently to retain less than $10 \%$ of the sodium and cesium present in the simulant.

- Sodium Hydroxide Production.

In the testing, analysis of the filtrate demonstrated $\mathrm{NaOH}$ production from the LIHT precipitation process. 


\subsection{IDENTIFICATION OF CRITICAL TECHNOLOGY ELEMENTS}

The process block diagram, process description, and process flowsheets from RPP-48377 and data quality objectives from RPP-PLAN-48088 were used in identifying the technology elements for the AREVA LiHT Process for Hanford waste treatment. The LiHT process design was evaluated by using the two sets of criteria from the U.S. Department of Energy, Office of Environment Management, Technology Readiness Assessment (TRA) / Technology Maturation Plan (TMP) Process Guide to identify technology elements that are critical to the successful operation of the LiHT process and that represent new or novel applications of the technology.

Using the described approach, the following technology elements were identified as CTEs:

\section{LiHT Process Design}

This CTE includes the lab-scale equipment, the LiHT process flow, and the test protocols for demonstrating the LiHT process for TRL 3. The process flow includes the following:

- Deliver filtered tank waste simulant to the process

- Precipitate LiHT solid from tank waste simulant

- Separate solid LiHT from the mother liquor containing $\mathrm{NaOH}$ by filtration

- Decontaminate the separated hydrotalcite with wash water

The TRL 3 testing used a 2-liter commercial laboratory reactor system. The test apparatus consisted of the 2-liter reactor, a reflux condenser configured to return condensate to the reactor, an agitator with speed indicator, a temperature indicator, and a jacket heater. Additional test items were a peristaltic pump with microbe tubing, a Büchner funnel, and $0.45 \mu \mathrm{m}$ PVDF Millipore Dura pore filter paper. RPP-48377 has a process flow diagram that shows the individual steps and interfaces of the LiHT process. Some steps that would be automated in a pilot-scale system (TRL 6) were either manually simulated or assumed, which the DOE Guide allows for TRL 3 testing.

2. Aluminum Precipitation from DST and SST Simulants

This CTE is one of four principle study questions for unknown conditions or unresolved issues of the LiHT Process. Aluminum precipitation is the chemical reaction that precipitates soluble sodium aluminate as a filterable solid and generates recoverable sodium hydroxide liquor in the filtrate. The recovered sodium hydroxide can be recycled to leach aluminum sludge from the DST and SST simulants.

The TRL 3 testing used SST and DST non-radioactive simulants to represent the chemical and physical properties of actual supernatant and sludge wastes stored in the Hanford SSTs and DSTs. The simulants were prepared using chemical formulation recipes in RPP-PLAN-48090 as a basis. The testing simulated this CTE by adding LiOH solution via a small peristaltic pump to the reactor vessel containing simulant. The process was manually performed by controlling the temperature and agitating the solution per prescribed testing protocols. Past testing showed LiHT can precipitate aluminum from DST and SST simulants. The most recent testing examined whether the LiHT process removed $85 \%$ of the soluble Al from Hanford SST and DST waste simulants. 


\section{Filtering of Precipitated LiHT Solids}

This CTE is one of four principle study questions for unknown conditions or unresolved issues of the LiHT Process. TRL 3 testing manually simulated this CTE by opening the bottom outlet of the reactor and allowing the slurry to drain into filter paper placed in the Büchner funnel. Chemical analysis was performed on samples of the filtrate and wet filter cake. The TRL 3 testing examined whether the solids produced from the reaction can be readily filtered under normal laboratory conditions. As the design of this CTE matures, the filtering capability will need to undergo further development, optimization, and testing. In the pilot-scale system (TRL 6), the LiHT filtering will be automated.

\section{Decontamination of LiHT Solids}

This CTE is one of four principle study questions for unknown conditions or unresolved issues of the LiHT Process. The TRL 3 testing followed prescribed test protocols to examine decontamination as a function of the number of washes. The reactor contents were manually filtered, the filter cake scraped from the funnel into a beaker, and the product filter cake manually washed. The filter cake was then re-pulped in wash water and the filter cake was sampled and analyzed after each wash increment. The extent of cesium decontamination was calculated from the results. The TRL 3 testing examined the ability of the LiHT process to generate solids that can be washed sufficiently to retain less than $10 \%$ of the sodium and cesium present in the simulant.

\section{Sodium Hydroxide Production}

This CTE is one of four principle study questions for unknown conditions or unresolved issues of the LiHT Process. In TRL 3 testing, filtrate was manually analyzed by following prescribed test protocols to evaluate $\mathrm{NaOH}$ production from the LiHT precipitation process. $\mathrm{NaOH}$ recovered in the filtrate can be recycled to leach aluminum sludge. This method eliminates the need to import sodium hydroxide for leaching. In TRL 3 testing, $\mathrm{NaOH}$ production was assessed but the $\mathrm{NaOH}$ was not recycled for leaching. The TRL 3 testing examined whether the LiHT process can generate 2 Moles of $\mathrm{NaOH}$ per mole of LiHT solids produced. The $\mathrm{NaOH}$ production will be optimized and developed with additional testing beyond the scope of TRL 3. In the pilot-scale system (TRL 6), $\mathrm{NaOH}$ production and recovery will be automated.

6. Operability of the LiHT Process

This CTE identifies the following operability items expected to be important for a pilot-scale system (TRLs 5 and 6) but which are beyond the scope of TRL 3 testing:

- Leachate delivery

- Sludge and liquid feeds through lines and pumps

- Internal and external interfacing

- Process Control and optimization

- Remoteability 
- Hazards

- Safety

- Recovery from failure

\subsection{ASSESSMENT OF TECHNOLOGY ELEMENTS}

Based on the AREVA 2010 bench-scale tests and the evaluation of the LiHT process design, CTEs 1 through 5 are at TRL 3 . The testing demonstrated the LiHT process and its CTEs by using tank waste simulants. Based on the test results, the overall TRL for the LiHT process is TRL 3. CTE 6 includes operability issues that are beyond the scope of TRL 3 lab-scale testing and evaluation. Because technology elements in CTE 6 are important to the later design and future technical maturity of a production-level LiHT system, they are identified in this TRE. Appendix B provides evaluations and the completed questionnaires with the basis and supporting documentation for each CTE.

\subsection{Current TRLs of CTEs}

Based on the AREVA 2010 bench-scale tests, the current TRL for each CTE is as follows:

1. LiHT Process Design

This CTE is at TRL 3. The lab-scale testing performed with the experimental apparatus described in Section 4.1.1 has demonstrated the main elements of the LiHT process flow. The testing demonstrated the individual steps of the LiHT process design shown in the LiHT block flow diagram, process description, and process flowsheets of RPP-48377. Steps manually simulated or assumed in the TRL 3 testing are parts of the process design that in later stages of development will need to be automated and integrated into the pilot-scale system.

2. Aluminum Precipitation from DST and SST Simulants

This CTE is at TRL 3. The lab-scale testing demonstrated that aluminum can be removed from tank waste simulants with the LiHT process, produce a filterable solid, and generate recoverable sodium hydroxide in the filtrate.

The TRL 3 testing used SST and DST non-radioactive simulants that are representative of the chemical and physical properties of actual supernatant wastes stored in Hanford single-shell and double-shell tanks. The testing assumed a leachate feed to the LiHT precipitation process. Leaching, which was not part of the test scope, was simulated by manually adding gibbsite to the DST and SST simulants in the two-liter reactor and then leaching the gibbsite at a near atmospheric boiling temperature of $105^{\circ} \mathrm{C}$.

To demonstrate aluminum precipitation, the TRL 3 testing manually added LiOH solution via peristaltic pump to the reactor vessel containing simulant. The precipitation process was then performed by controlling the temperature and agitating the solution per prescribed testing protocols. Prior testing showed LiHT can precipitate aluminum from DST and SST simulants. The TRL 3 testing showed the LiHT process removes more than $85 \%$ of the soluble Al from Hanford SST and DST waste simulant. 


\section{Filtering of Precipitated LiHT Solids}

This CTE is at TRL 3. The lab-scale testing manually simulated this CTE by opening the bottom outlet of the reactor and allowing the slurry to drain onto filter paper placed in the Büchner funnel inlet and outlets. Chemical analyses were performed on samples of the filtrate and wet filter cake. The results of the TRL 3 testing show the LiHT process produces solids that can be readily filtered under normal laboratory conditions. The filtering capability will be optimized and further developed with additional testing at TRL 4 and beyond. In the pilot-scale system (TRL 6), the filtering will be automated.

4. Decontamination of LiHT Solids

This CTE is at TRL 3. The testing demonstrated the LiHT process generates solids that can be washed sufficiently to retain less than $10 \%$ of the sodium and cesium. This CTE be optimized and further developed with additional testing that is beyond the scope of TRL 3 . In the pilot-scale system (TRL 6), decontamination will be automated.

5. Sodium Hydroxide Production

This CTE is at TRL 3. The testing demonstrated the generation of $\mathrm{NaOH}$ as a byproduct of the LiHT precipitation. $\mathrm{NaOH}$ recovered in the filtrate can be recycled to leach aluminum sludge.

6. Operability of the LiHT Process

The current TRL of this CTE was not assessed because it represents engineering issues that need to be evaluated in later stages of system design and development. As the LiHT process matures and increases in scale, these engineering issues will be important to the successful operation of a production-scale system. This following operability issues need to be evaluated when the system reaches higher levels of development:

(1) Leachate delivery (assumed at TRL 3)

(2) Sludge and liquid feeds through lines and pumps

The TRL 3 lab-scale testing involved all unit operations of interest. Interfaces for sludge and liquid feeds through lines and pumps were simulated. These feeds will be essential to the successful operation of the engineering scale LiHT Processing System.

(3) Internal and external interfacing

The testing of all internal and external interfacing for the LiHT System were beyond the scope of the TRL 3 lab-scale tests. Internal and external interfaces of the LiHT process were manually simulated using the lab-scale test apparatus.

(4) Process control and optimization

As the scale and fidelity of the LiHT process increases, the process control and process parameters will need further testing and evaluation. 
As the scale and fidelity of the LiHT process advances the testing on actual waste will require remote operations.

(6) Hazards

The application of the LiHT process to actual waste involves caustic materials and radiation.

(7) Safety

The handling of hazardous materials will require safety procedures, safety equipment, monitoring systems, protective clothing, and shielding from radiation.

(8) Recovery from failure

Specific procedures and mitigation capabilities will be needed to recover from plugged lines, broken lines, clogged pumps, pump failure, and failed monitoring systems.

\subsection{Technical Risks for CTEs}

There is uncertainty in how CTEs 1 through 5 would perform at larger scales with more complex simulants. There is also uncertainty in the extent of parametric testing that would be needed to optimize the process design to meet production-level performance objectives. Specific areas of technical risk include:

- Contamination of LiHT and undesirable reactions due to cationic inclusions, anionic adsorption, trapping of contaminants.

- Incomplete solubility data on many lithium salts with potential to impact the optimization of the process.

- Competing anionic precipitation reactions and unwanted side reactions.

- Effects of simulant composition on LiHT product quality with potential to impact estimated compliance with disposal requirements.

Technical risks for CTE 6 were not evaluated because they are associated with operability and engineering issues that are beyond the scope of the TRL 3 evaluation, which focused only on the LiHT process. Operability risks need to be evaluated at later stages of the system design and development.

\subsection{SUMMARY}

The results of this TRE support the WPRC evaluation of the AREVA LiHT Process as a supplemental pretreatment option for Hanford tank waste as part of the River Protection Plan (RPP) mission. 
This TRE was based on a process block flow diagram, process description, and process flowsheets and the results of 2-liter bench-scale validation tests for the AREVA LiHT Process. The TRE identifies six critical technology elements (CTEs) of the LiHT process, five of which were evaluated and found to have achieved a technology readiness level (TRL) of 3 . The sixth CTE identified operability issues that are beyond the scope of TRL 3 but will need to be considered in further stages of system design and maturity.

It was determined that the LiHT process has reached an overall TRL of 3, which means the research, development, and testing have validated the LiHT process and its CTEs in laboratoryscale testing on tank waste simulants. The TRL 3 testing included the detailed definition and evaluation of parameters of interest and validation by comparison of test results to analytical predictions and data quality objectives for the critical subsystems.

The results of this TRE would support efforts to develop strategies to mature the LiHT CTEs. Specific actions for maturing these CTEs to TRL 4 and beyond to TRL 6 need to be detailed in the TMP. It is recommended that the items under the sixth CTE be evaluated at either TRL 5 or TRL 6 as the LiHT Process approaches and enters the pilot-scale level of development, design, and testing. 
RPP-48379, Rev. 0

\subsection{REFERENCES}

U.S. Department of Energy, Office of Environment Management, Technology Readiness Assessment (TRA) / Technology Maturation Plan (TMP) Process Guide, 2008.

U.S. Department of Energy, Office of Management, Technology Readiness Assessment Guide, DOE G413.3-4, October 2009.

RPP-48377-000, Alumina Removal and Sodium Hydroxide Regeneration from Hanford Waste by Lithium Hydrotalcite Precipitation - Process Model Flowsheet, AREVA, 2010.

RPP-PLAN-48088-000, Data Quality Objectives for Lithium Hydrotalcite Process Validation, AREVA, 2010.

RPP-43328-000, Test Program for Alumina Removal and Sodium Hydroxide Regeneration from Hanford Waste by Lithium Hydrotalcite Precipitation, AREVA, 2010.

RPP-RPT-48380-000, Alumina Removal and Sodium Regeneration from Hanford Waste by Lithium Hydrotalcite Precipitation - Laboratory Scale Validation on Waste Simulants - Test Report, AREVA, 2010.

RPP-PLAN-48085-000, Technology Maturation Plan for Alumina Removal and Sodium Hydroxide Regeneration from Hanford Waste by Lithium Hydrotalcite Precipitation, AREVA, 2010.

RPP-48376-000, Alumina Removal and Sodium Hydroxide Regeneration from Hanford Waste by Lithium Hydrotalcite Precipitation - Summary of prior lab-scale testing, AREVA, 2010.

RPP-48089-000, Lithium Hydrotalcite Simulant Preliminary Requirements, AREVA, January 2010.

RPP-PLAN-48090-000, Lithium Hydrotalcite Precipitation Development Planning - Single-Shell Tank Supernatant Tests, AREVA, April 2010.

RPP-PLAN-48091-000, Lithium Hydrotalcite Precipitation Development Planning - Double-Shell Tank Supernatant Tests, AREVA, April 2010.

RPP-PLAN-48381-000, Site Specific Health and Safety Plan for Lithium Hydrotalcite Pretreatment Planning, AREVA, September 2009.

Huber, H.J., J.B. Duncan, and G.A. Cooke, Report on Qualitative Validation Experiments Using Lithium-Aluminum Layer Double-Hydroxides for the Reduction of Aluminum from the Waste Treatment Plant Feedstock, LAB-RPT-10-00003, Revision 0, Washington River Protection Solutions, March 2010.

PCT International Application PCT/US2008/076589, AREVA, 2008.

Duan, X. and D.G. Evans, Layered Double Hydroxides (Structure and Bonding), ISSN 0081-5993. 


\section{APPENDIX A1.0 - CRITICAL TECHNOLOOGY ELEMENTS}

\section{Identification of CTEs for the LiHT Process}

Based on the methods described in Section 2.2.2 and the evaluation discussed in Section 4.0, the following technology elements (described in Section 4.0) were identified as CTEs that are critical to the successful operation of the LiHT Process:

1. LiHT Process Design

2. Aluminum Precipitation from DST and SST Simulants

3. Filtering of Precipitated LiHT Solids

4. Decontamination of LiHT Solids

5. Sodium Hydroxide Production

6. Operability of the LiHT Process

Appendix B provides the detailed TRL 3 evaluation for each of these CTEs. Most programmatic criteria were beyond the scope of this CTE, which focused on technical maturity, and were therefore answered N/A. 


\section{APPENDIX B1.0 - TRL EVALUATION}

\section{TRL Evaluation CTEs for the LiHT Process}

Tables B.1 through B.12 in this appendix provide the TRL assessments for CTEs 1 through 6 of the LiHT Process per criteria in DOE Technology Readiness Assessment Guide, Tables F.1 through F.3).

Table B.1: Top-Level Evaluation of TRL for CTE 1

\section{LiHT Process Design}

\begin{tabular}{|c|c|c|c|}
\hline \multicolumn{2}{|r|}{ Top-Level Questions } & Yes/No & \multirow{2}{*}{$\begin{array}{c}\text { If Yes, Then } \\
\text { Basis and Supporting Documentation }\end{array}$} \\
\hline TRL 9 & $\begin{array}{l}\text { Has the actual equipment/process successfully } \\
\text { operated in the full operational environment } \\
\text { (hot operations)? }\end{array}$ & No & \\
\hline TRL 8 & $\begin{array}{l}\text { Has the actual equipment/process successfully } \\
\text { operated in a limited operational environment } \\
\text { (hot commissioning)? }\end{array}$ & No & \\
\hline TRL 7 & $\begin{array}{l}\text { Has the actual equipment/process successfully } \\
\text { operated in the relevant operational } \\
\text { environment (cold commissioning)? }\end{array}$ & No & \\
\hline TRL 6 & $\begin{array}{l}\text { Has prototypical engineering scale } \\
\text { equipment/process testing been demonstrated } \\
\text { in a relevant environment; to include testing } \\
\text { of the safety function? }\end{array}$ & No & \\
\hline TRL 5 & $\begin{array}{l}\text { Has bench-scale equipment/process testing } \\
\text { been demonstrated in a relevant environment? }\end{array}$ & No & \\
\hline TRL 4 & $\begin{array}{l}\text { Has laboratory-scale testing of similar } \\
\text { equipment systems been completed in a } \\
\text { simulated environment? }\end{array}$ & No & \\
\hline TRL 3 & $\begin{array}{l}\text { Has equipment and process analysis and proof } \\
\text { of concept been demonstrated in a simulated } \\
\text { environment? }\end{array}$ & Yes & $\begin{array}{l}\text { Analytical studies and lab-scale validation } \\
\text { testing have validated the LiHT Process. } \\
\text { Parameters of interest have been identified. } \\
\text { Process diagrams, descriptions, and flowsheets } \\
\text { have been developed. Lab-scale tests } \\
\text { (RPP-RPT- } 48380, \text { Rev. } 0 \text { ) have successfully } \\
\text { demonstrated the LiHT Process including the } \\
\text { removal of aluminum from tank waste simulants, } \\
\text { production of a filterable solid, and the } \\
\text { regeneration of sodium hydroxide. }\end{array}$ \\
\hline TRL 2 & $\begin{array}{l}\text { Has an equipment and process concept been } \\
\text { formulated? }\end{array}$ & Yes & \\
\hline TRL 1 & $\begin{array}{l}\text { Have the basic process technology process } \\
\text { principles been observed and reported? }\end{array}$ & Yes & \\
\hline
\end{tabular}


Table B.2: Evaluation of TRL 3 Questions for CTE 1

\begin{tabular}{|c|c|c|c|c|}
\hline \multicolumn{5}{|c|}{ TRL 3 Questions for CTE 1 - LiHT Process Design } \\
\hline $\mathbf{T} / \mathbf{P} / \mathbf{M}$ & $\mathbf{Y} / \mathbf{N}$ & & Criteria & Basis and Supporting Documentation \\
\hline $\mathrm{T}$ & $\mathrm{Y}$ & & Academic (basic science) environment & $\begin{array}{l}\text { Basic science and the LiHT process are described in } \\
\text { RPP- } 48377, \text { RPP- } 43328 \text {, RPP-PLAN- } 48085 \text {, } \\
\text { RPP- } 48376 \text {, and "Report on Qualitative Validation } \\
\text { Experiments Using Lithium-Aluminum Layer Double- } \\
\text { Hydroxides for the Reduction of Aluminum from the } \\
\text { Waste Treatment Plant Feedstock." } \\
\text { Lab-scale testing (RPP-RPT- } 48380 \text { ) has demonstrated } \\
\text { that aluminum can be removed from tanks waste } \\
\text { simulants with the LiHT process, produce a filterable } \\
\text { solid, and generate recoverable NaOH in the filtrate. }\end{array}$ \\
\hline $\mathrm{P}$ & N/A & (2) & $\begin{array}{l}\text { Some key process and safety } \\
\text { requirements are identified }\end{array}$ & $\begin{array}{l}\text { Not part of the scope of this TRE. Safety requirements } \\
\text { are identified in RPP-PLAN- } 48381 \text {. }\end{array}$ \\
\hline $\mathrm{T}$ & $\mathrm{Y}$ & & $\begin{array}{l}\text { Predictions of elements of technology } \\
\text { capability validated by analytical studies }\end{array}$ & $\begin{array}{l}\text { Predictions of elements of the technology capability } \\
\text { are provided in RPP- } 48377 \text { and RPP-PLAN- } 48088 \text { and } \\
\text { validated by testing documented in RPP-RPT- } 48380 \text {, } \\
\text { RPP- } 48376 \text {, and "Report on Qualitative Validation } \\
\text { Experiments Using Lithium-Aluminum Layer Double- } \\
\text { Hydroxides for the Reduction of Aluminum from the } \\
\text { Waste Treatment Plant Feedstock." } \\
\text { In situ aluminum leaching was demonstrated in full- } \\
\text { scale operation in Tank } 51 \text { by Savannah River National } \\
\text { Laboratory. }\end{array}$ \\
\hline $\mathrm{P}$ & $\mathrm{Y}$ & & $\begin{array}{l}\text { The basic science has been validated at } \\
\text { the laboratory scale }\end{array}$ & See (3). \\
\hline $\mathrm{T}$ & $\mathrm{Y}$ & (5) & $\begin{array}{l}\text { Science known to extent that } \\
\text { mathematical and/or computer models } \\
\text { and simulations are possible }\end{array}$ & $\begin{array}{l}\text { Thermochemical data have been used in the } \\
\text { Environmental Simulation Program (ESP) to simulate } \\
\text { the LiHT process (RPP-48376). }\end{array}$ \\
\hline $\mathrm{P}$ & N/A & (6) & $\begin{array}{l}\text { Preliminary system performance } \\
\text { characteristics and measures have been } \\
\text { identified and estimated }\end{array}$ & Not part of the scope of this TRE. \\
\hline $\mathrm{T}$ & $\mathrm{Y}$ & (7) & $\begin{array}{l}\text { Predictions of elements of technology } \\
\text { capability validated by Modeling and } \\
\text { Simulation (M\&S) }\end{array}$ & See (2) and (5) \\
\hline M & $\mathrm{Y}$ & (8) & $\begin{array}{l}\text { No system components, just basic } \\
\text { laboratory research equipment to verify } \\
\text { physical principles }\end{array}$ & $\begin{array}{l}\text { See (2). } \\
\text { The LiHT Block Diagram, Process Description, and } \\
\text { Process Flowsheets show the conceptual design of the } \\
\text { LiHT process and system components. }\end{array}$ \\
\hline $\mathrm{T}$ & Y & (9) & $\begin{array}{l}\text { Laboratory experiments verify feasibility } \\
\text { of application }\end{array}$ & See (5) and (8) \\
\hline $\mathrm{T}$ & Y & (10) & $\begin{array}{l}\text { Predictions of elements of technology } \\
\text { capability validated by laboratory } \\
\text { experiments }\end{array}$ & See (5) and (8) \\
\hline $\mathrm{P}$ & $\mathrm{N} / \mathrm{A}$ & $(11$ & $\begin{array}{l}\text { Customer representative identified to } \\
\text { work with development team }\end{array}$ & Not part of the scope of this TRE. \\
\hline
\end{tabular}


RPP-48379, Rev. 0

\begin{tabular}{|c|c|c|c|}
\hline \multicolumn{4}{|c|}{ TRL 3 Questions for CTE 1 - LiHT Process Design } \\
\hline $\mathbf{T} / \mathbf{P} / \mathbf{M}$ & $\mathbf{Y} / \mathbf{N}$ & Criteria & Basis and Supporting Documentation \\
\hline $\mathrm{P}$ & N/A & $\begin{array}{l}\text { (12) Customer participates in requirements } \\
\text { generation }\end{array}$ & Not part of the scope of this TRE. \\
\hline $\mathrm{T}$ & Y & $\begin{array}{l}\text { (13) Requirements tracking system defined to } \\
\text { management requirements creep }\end{array}$ & $\begin{array}{l}\text { Requirements will be tracked with the Technology } \\
\text { Maturation Plan. }\end{array}$ \\
\hline $\mathrm{T}$ & $\mathrm{Y}$ & $\begin{array}{l}\text { (14) Key process parameters/variables and } \\
\text { associated hazards have begun to be } \\
\text { identified. }\end{array}$ & $\begin{array}{l}\text { Key process parameters/variables and associated } \\
\text { hazards are identified in RPP-48377, RPP- } 48376 \text {, } \\
\text { RPP-48089, RPP-PLAN-48090, and } \\
\text { RPP-PLAN-48091. }\end{array}$ \\
\hline M & $\mathrm{Y}$ & $\begin{array}{l}\text { (15) Design techniques have been } \\
\text { identified/developed }\end{array}$ & See $(2),(5)$ and $(8)$ \\
\hline $\mathrm{T}$ & $\mathrm{Y}$ & $\begin{array}{l}\text { (16) Paper studies indicate that system } \\
\text { components ought to work together }\end{array}$ & See (2), (5), and (8). \\
\hline $\mathrm{P}$ & $\mathrm{N} / \mathrm{A}$ & (17) Customer identifies technology need date & Not part of the scope of this TRE. \\
\hline $\mathrm{T}$ & $\mathrm{Y}$ & $\begin{array}{l}\text { (18) Performance metrics for the system are } \\
\text { established (What must it do?) }\end{array}$ & $\begin{array}{l}\text { Process yields and cesium decontamination factor after } \\
\text { treating the LiHT precipitate are documented in } \\
\text { RPP-PLAN- } 48088 \text { and RPP- } 48376 \text {. }\end{array}$ \\
\hline $\mathrm{P}$ & N/A & (19) Scaling studies have been started & Not part of the scope of this TRE. \\
\hline M & $\mathrm{Y}$ & $\begin{array}{l}\text { (20) Current manufacturability concepts } \\
\text { assessed }\end{array}$ & See $(2),(5)$ and $(8)$ \\
\hline M & $\mathrm{Y}$ & $\begin{array}{l}\text { (21) Sources of key components for } \\
\text { laboratory testing identified }\end{array}$ & See $(2),(5)$ and $(8)$ \\
\hline $\mathrm{T}$ & Y & (22) Scientific feasibility fully demonstrated & See $(2),(5)$ and $(8)$ \\
\hline $\mathrm{T}$ & $\mathrm{Y}$ & $\begin{array}{l}\text { (23) Analysis of present state of the art shows } \\
\text { that technology fills a need }\end{array}$ & $\begin{array}{l}\text { TRL-3 testing documented in RPP- } 43328 \text { has shown } \\
\text { the LiHT process will fill Hanford site waste treatment } \\
\text { technology needs identified in RPP-PLAN- } 48088 \text {. } \\
\text { The LiHT process will reduce the amount of sodium in } \\
\text { the form of NaOH needed to dissolve Hanford DST } \\
\text { and SST waste aluminum, decrease the WTP } \\
\text { processing time and operational cost, and decrease the } \\
\text { volumes of ILAW glass produced for storage and } \\
\text { disposal. }\end{array}$ \\
\hline $\mathrm{P}$ & N/A & (24) Risk areas identified in general terms & $\begin{array}{l}\text { Not part of the scope of this TRE. Technical risk } \\
\text { briefly discussed in Section } 5.2 \text {. }\end{array}$ \\
\hline $\mathrm{P}$ & $\mathrm{N} / \mathrm{A}$ & (25) Risk mitigation strategies identified & $\begin{array}{l}\text { Not part of the scope of this TRE. Technical risk } \\
\text { briefly discussed in Section } 5.2 \text {. }\end{array}$ \\
\hline $\mathrm{P}$ & $\mathrm{Y}$ & $\begin{array}{l}\text { (26) Rudimentary best value analysis } \\
\text { performed for operations }\end{array}$ & $\begin{array}{l}\text { Technical evaluation. Programmatic best value } \\
\text { analysis not within the scope of this TRE. }\end{array}$ \\
\hline $\mathrm{T}$ & $\mathrm{Y}$ & $\begin{array}{l}\text { (27) Key physical and chemical properties } \\
\text { have been characterized for a number of } \\
\text { waste samples }\end{array}$ & $\begin{array}{l}\text { Thermochemical data were used in the Environmental } \\
\text { Simulation Program (ESP) to simulate the LiHT } \\
\text { process. } \\
\text { The composition and quantities of Hanford DST and } \\
\text { SST wastes are documented in PNNL-11450. }\end{array}$ \\
\hline
\end{tabular}


RPP-48379, Rev. 0

TRL 3 Questions for CTE 1 - LiHT Process Design

\begin{tabular}{|c|c|l|l|}
\hline T/P/M & Y/N & \multicolumn{1}{|c|}{ Criteria } & \multicolumn{1}{c|}{ Basis and Supporting Documentation } \\
\hline $\mathrm{T}$ & $\mathrm{Y}$ & $\begin{array}{l}\text { (28) A simulant has been developed that } \\
\text { approximates key waste properties }\end{array}$ & $\begin{array}{l}\text { Development of simulant(s) to approximate key waste } \\
\text { properties is documented in RPP-48377, RPP-48089, } \\
\text { RPP-PLAN-48090, and RPP-PLAN-48091. }\end{array}$ \\
\hline $\mathrm{T}$ & $\mathrm{Y}$ & $\begin{array}{l}\text { (29) Laboratory scale tests on a simulant have } \\
\text { been completed }\end{array}$ & $\begin{array}{l}\text { Independent lab-scale tests of the Georgia Tech } \\
\text { experiments were completed on Hanford DST and SST } \\
\text { simulants by AREVA as described in RPP-43328. }\end{array}$ \\
\hline $\mathrm{T}$ & $\mathrm{Y}$ & $\begin{array}{l}\text { (30) Specific waste(s) and waste site(s) has } \\
\text { (have) been defined }\end{array}$ & $\begin{array}{l}\text { The LiHT process will be used for treatment of } \\
\text { Hanford SST and DST wastes by Hanford WTP at } \\
\text { facilities now under construction. }\end{array}$ \\
\hline $\mathrm{T}$ & $\mathrm{Y}$ & $\begin{array}{l}\text { (31) The individual system components have } \\
\text { been tested at the laboratory scale }\end{array}$ & See (2), (5), and (8) \\
\hline
\end{tabular}


Table B.3: Top-Level Evaluation of TRL for CTE 2

\section{Aluminum Precipitation from DST and SST Simulants}

\begin{tabular}{|c|c|c|c|}
\hline \multicolumn{2}{|r|}{ Top-Level Questions } & Yes/No & $\begin{array}{l}\text { If Yes, Then } \\
\text { Basis and Sunporting Documentation }\end{array}$ \\
\hline TRL 9 & $\begin{array}{l}\text { Has the actual equipment/process successfully } \\
\text { operated in the full operational environment } \\
\text { (hot operations)? }\end{array}$ & No & \\
\hline TRL 8 & $\begin{array}{l}\text { Has the actual equipment/process successfully } \\
\text { operated in a limited operational environment } \\
\text { (hot commissioning)? }\end{array}$ & No & \\
\hline TRL 7 & $\begin{array}{l}\text { Has the actual equipment/process successfully } \\
\text { operated in the relevant operational } \\
\text { environment (cold commissioning)? }\end{array}$ & No & \\
\hline TRL 6 & $\begin{array}{l}\text { Has prototypical engineering scale } \\
\text { equipment/process testing been demonstrated } \\
\text { in a relevant environment; to include testing } \\
\text { of the safety function? }\end{array}$ & No & \\
\hline TRL 5 & $\begin{array}{l}\text { Has bench-scale equipment/process testing } \\
\text { been demonstrated in a relevant environment? }\end{array}$ & No & \\
\hline TRL 4 & $\begin{array}{l}\text { Has laboratory-scale testing of similar } \\
\text { equipment systems been completed in a } \\
\text { simulated environment? }\end{array}$ & No & \\
\hline TRL 3 & $\begin{array}{l}\text { Has equipment and process analysis and proof } \\
\text { of concept been demonstrated in a simulated } \\
\text { environment? }\end{array}$ & Yes & $\begin{array}{l}\text { Testing has demonstrated that aluminum can be } \\
\text { removed from tank waste simulants with the } \\
\text { LiHT process, produce a filterable solid, and } \\
\text { generate recoverable } \mathrm{NaOH} \text { in the filtrate. }\end{array}$ \\
\hline TRL 2 & $\begin{array}{l}\text { Has an equipment and process concept been } \\
\text { formulated? }\end{array}$ & Yes & \\
\hline TRL 1 & $\begin{array}{l}\text { Have the basic process technology process } \\
\text { principles been observed and reported? }\end{array}$ & Yes & \\
\hline
\end{tabular}


Table B.4: Evaluation of TRL 3 Questions for CTE 2

\begin{tabular}{|c|c|c|c|}
\hline \multicolumn{4}{|c|}{ TRL 3 Questions for CTE 2 - Aluminum Precipitation from DST and SST Simulants } \\
\hline $\mathbf{T} / \mathbf{P} / \mathbf{M}$ & $\mathrm{Y} / \mathrm{N}$ & Criteria & Basis and Supporting Documentation \\
\hline $\mathrm{T}$ & $\mathrm{Y}$ & (1) Academic (basic science) environment & $\begin{array}{l}\text { Basic science and the LiHT process are described in } \\
\text { RPP- } 48377, \mathrm{RPP}-43328, \mathrm{RPP}-\mathrm{RPT}-48380 \text {, } \\
\text { RPP-PLAN-48085, RPP-48376, and "Report on } \\
\text { Qualitative Validation Experiments Using Lithium- } \\
\text { Aluminum Layer Double-Hydroxides for the Reduction } \\
\text { of Aluminum from the Waste Treatment Plant } \\
\text { Feedstock." } \\
\text { Lab-scale testing has demonstrated that aluminum can } \\
\text { be removed from tanks waste simulants with the LiHT } \\
\text { process, produce a filterable solid, and generate } \\
\text { recoverable NaOH in the filtrate. }\end{array}$ \\
\hline $\mathrm{P}$ & N/A & $\begin{array}{l}\text { (2) Some key process and safety } \\
\text { requirements are identified }\end{array}$ & $\begin{array}{l}\text { Not part of the scope of this TRE. Safety requirements } \\
\text { are identified in RPP-PLAN- } 48381 \text {. }\end{array}$ \\
\hline $\mathrm{T}$ & $\mathrm{Y}$ & $\begin{array}{l}\text { (3) Predictions of elements of technology } \\
\text { capability validated by analytical studies }\end{array}$ & $\begin{array}{l}\text { Predictions of elements of the technology capability } \\
\text { are provided in RPP- } 48377 \text { and RPP-PLAN- } 48088 \text { and } \\
\text { validated by testing documented in RPP-RPT- } 48380 \text {, } \\
\text { RPP- } 48376 \text {, and "Report on Qualitative Validation } \\
\text { Experiments Using Lithium-Aluminum Layer Double- } \\
\text { Hydroxides for the Reduction of Aluminum from the } \\
\text { Waste Treatment Plant Feedstock." } \\
\text { In situ aluminum leaching was demonstrated in full- } \\
\text { scale operation in Tank } 51 \text { by Savannah River National } \\
\text { Laboratory. }\end{array}$ \\
\hline $\mathrm{P}$ & $\mathrm{Y}$ & $\begin{array}{l}\text { (4) The basic science has been validated at } \\
\text { the laboratory scale }\end{array}$ & See (3). \\
\hline $\mathrm{T}$ & Y & $\begin{array}{l}\text { (5) Science known to extent that } \\
\text { mathematical and/or computer models } \\
\text { and simulations are possible }\end{array}$ & $\begin{array}{l}\text { Thermochemical data have been used in the } \\
\text { Environmental Simulation Program (ESP) to simulate } \\
\text { the LiHT process (RPP- } 48376 \text { ). }\end{array}$ \\
\hline $\mathrm{P}$ & Y & $\begin{array}{l}\text { (6) Preliminary system performance } \\
\text { characteristics and measures have been } \\
\text { identified and estimated }\end{array}$ & $\operatorname{See}(2)$ \\
\hline $\mathrm{T}$ & Y & $\begin{array}{l}\text { (7) Predictions of elements of technology } \\
\text { capability validated by Modeling and } \\
\text { Simulation (M\&S) }\end{array}$ & See (2) and (5) \\
\hline M & $\mathrm{Y}$ & $\begin{array}{l}\text { (8) No system components, just basic } \\
\text { laboratory research equipment to verify } \\
\text { physical principles }\end{array}$ & $\begin{array}{l}\text { See (2). } \\
\text { The LiHT Block Diagram and Process Flowsheets } \\
\text { shows the conceptual design of the LiHT process and } \\
\text { system components. }\end{array}$ \\
\hline $\mathrm{T}$ & Y & $\begin{array}{l}\text { (9) Laboratory experiments verify feasibility } \\
\text { of application }\end{array}$ & See (5) and (8) \\
\hline $\mathrm{T}$ & $\mathrm{Y}$ & $\begin{array}{l}\text { (10) Predictions of elements of technology } \\
\text { capability validated by laboratory } \\
\text { experiments }\end{array}$ & See (5) and (8) \\
\hline $\mathrm{P}$ & $\mathrm{N} / \mathrm{A}$ & $\begin{array}{l}\text { (11) Customer representative identified to } \\
\text { work with development team }\end{array}$ & Not part of the scope of this TRE. \\
\hline
\end{tabular}


TRL 3 Questions for CTE 2 - Aluminum Precipitation from DST and SST Simulants

\begin{tabular}{|c|c|c|c|}
\hline $\mathbf{T} / \mathbf{P} / \mathbf{M}$ & $\mathbf{Y} / \mathbf{N}$ & Criteria & Basis and Supporting Documentation \\
\hline $\mathrm{P}$ & N/A & $\begin{array}{l}\text { (12) Customer participates in requirements } \\
\text { generation }\end{array}$ & Not part of the scope of this TRE. \\
\hline $\mathrm{T}$ & $\mathrm{Y}$ & $\begin{array}{l}\text { (13) Requirements tracking system defined to } \\
\text { management requirements creep }\end{array}$ & $\begin{array}{l}\text { Requirements will be tracked with the Technology } \\
\text { Maturation Plan. }\end{array}$ \\
\hline $\mathrm{T}$ & $\mathrm{Y}$ & $\begin{array}{l}\text { (14) Key process parameters/variables and } \\
\text { associated hazards have begun to be } \\
\text { identified. }\end{array}$ & $\begin{array}{l}\text { Key process parameters/variables and associated } \\
\text { hazards are identified in RPP-48377, RPP-43328, } \\
\text { RPP-48376, RPP-48089; RPP-PLAN-48090, and } \\
\text { RPP-PLAN-48091. }\end{array}$ \\
\hline M & $\mathrm{Y}$ & $\begin{array}{l}\text { (15) Design techniques have been } \\
\text { identified/developed }\end{array}$ & See $(2),(5)$ and $(8)$ \\
\hline $\mathrm{T}$ & $\mathrm{Y}$ & $\begin{array}{l}\text { (16) Paper studies indicate that system } \\
\text { components ought to work together }\end{array}$ & See (2), (5), and (8). \\
\hline $\mathrm{P}$ & $\mathrm{N} / \mathrm{A}$ & (17) Customer identifies technology need date & Not part of the scope of this TRE. \\
\hline $\mathrm{T}$ & $\mathrm{Y}$ & $\begin{array}{l}\text { (18) Performance metrics for the system are } \\
\text { established (What must it do?) }\end{array}$ & $\begin{array}{l}\text { Process yields and cesium decontamination factor after } \\
\text { treating the LiHT precipitate are documented in } \\
\text { RPP-PLAN-48088 and RPP- } 48376 \text {. }\end{array}$ \\
\hline $\mathrm{P}$ & $\mathrm{N} / \mathrm{A}$ & (19) Scaling studies have been started & Not part of the scope of this TRE. \\
\hline M & $\mathrm{Y}$ & $\begin{array}{l}\text { (20) Current manufacturability concepts } \\
\text { assessed }\end{array}$ & See $(2),(5)$ and $(8)$ \\
\hline M & Y & $\begin{array}{l}\text { (21) Sources of key components for } \\
\text { laboratory testing identified }\end{array}$ & See $(2),(5)$ and $(8)$ \\
\hline $\mathrm{T}$ & Y & (22) Scientific feasibility fully demonstrated & See $(2),(5)$ and $(8)$ \\
\hline $\mathrm{T}$ & $\mathrm{Y}$ & $\begin{array}{l}\text { (23) Analysis of present state of the art shows } \\
\text { that technology fills a need }\end{array}$ & $\begin{array}{l}\text { TRL-3 testing documented in RPP-RPT- } 48380 \text { has } \\
\text { shown the LiHT process will fill Hanford site waste } \\
\text { treatment technology needs identified in } \\
\text { RPP-PLAN-48088. } \\
\text { The LiHT process will reduce the amount of sodium in } \\
\text { the form of NaOH needed to dissolve Hanford DST } \\
\text { and SST waste aluminum, decrease the WTP } \\
\text { processing time and operational cost, and decrease the } \\
\text { volumes of ILAW glass produced for storage and } \\
\text { disposal. }\end{array}$ \\
\hline $\mathrm{P}$ & $\mathrm{N} / \mathrm{A}$ & (24) Risk areas identified in general terms & $\begin{array}{l}\text { Not part of the scope of this TRE. Technical risk } \\
\text { briefly discussed in Section } 5.2 \text {. }\end{array}$ \\
\hline $\mathrm{P}$ & $\mathrm{N} / \mathrm{A}$ & (25) Risk mitigation strategies identified & $\begin{array}{l}\text { Not part of the scope of this TRE. Technical risk } \\
\text { briefly discussed in Section } 5.2 \text {. }\end{array}$ \\
\hline $\mathrm{P}$ & $\mathrm{N} / \mathrm{A}$ & $\begin{array}{l}\text { (26) Rudimentary best value analysis } \\
\text { performed for operations }\end{array}$ & Not part of the scope of this TRE. \\
\hline
\end{tabular}


RPP-48379, Rev. 0

TRL 3 Questions for CTE 2 - Aluminum Precipitation from DST and SST Simulants

\begin{tabular}{|c|c|l|l|}
\hline T/P/M & $\mathbf{Y} / \mathbf{N}$ & \multicolumn{1}{|c|}{ Criteria } & \multicolumn{1}{c|}{ Basis and Supporting Documentation } \\
\hline $\mathrm{T}$ & $\mathrm{Y}$ & $\begin{array}{l}\text { (27) Key physical and chemical properties } \\
\text { have been characterized for a number of } \\
\text { waste samples }\end{array}$ & $\begin{array}{l}\text { Thermochemical data were used in the Environmental } \\
\text { Simulation Program (ESP) to simulate the LiHT } \\
\text { process. } \\
\text { The composition and quantities of Hanford DST and } \\
\text { SST wastes are documented in PNNL-11450. }\end{array}$ \\
\hline $\mathrm{T}$ & $\mathrm{Y}$ & $\begin{array}{c}\text { (28) A simulant has been developed that } \\
\text { approximates key waste properties }\end{array}$ & $\begin{array}{l}\text { Development of simulant(s) to approximate key waste } \\
\text { properties is documented in RPP-48377, RPP48089, } \\
\text { RPP-PLAN-48090, RPP-PLAN-48091. }\end{array}$ \\
\hline $\mathrm{T}$ & $\mathrm{Y}$ & $\begin{array}{c}\text { (29) Laboratory scale tests on a simulant have } \\
\text { been completed }\end{array}$ & $\begin{array}{l}\text { Independent lab-scale tests of the Georgia Tech } \\
\text { experiments were completed on Hanford DST and SST } \\
\text { simulants by AREVA as described in RPP-43328. }\end{array}$ \\
\hline $\mathrm{T}$ & $\mathrm{Y}$ & $\begin{array}{l}\text { (30) Specific waste(s) and waste site(s) has } \\
\text { (have) been defined }\end{array}$ & $\begin{array}{l}\text { The LiHT process will be used for treatment of } \\
\text { Hanford SST and DST wastes by Hanford WTP at } \\
\text { facilities now under construction. }\end{array}$ \\
\hline $\mathrm{T}$ & $\mathrm{Y}$ & $\begin{array}{l}\text { (31) The individual system components have } \\
\text { been tested at the laboratory scale }\end{array}$ & See (2), (5), and (8) \\
\hline
\end{tabular}


Table B.5: Top-Level Evaluation of TRL for CTE 3

Filtering of Precipitated LiHT Solids

\begin{tabular}{|c|c|c|c|}
\hline \multicolumn{2}{|r|}{ Top-Level Questions } & Yes/No & If Yes, Then \\
\hline TRL 9 & $\begin{array}{l}\text { Has the actual equipment/process successfully } \\
\text { operated in the full operational environment } \\
\text { (hot operations)? }\end{array}$ & No & \\
\hline TRL 8 & $\begin{array}{l}\text { Has the actual equipment/process successfully } \\
\text { operated in a limited operational environment } \\
\text { (hot commissioning)? }\end{array}$ & No & \\
\hline TRL 7 & $\begin{array}{l}\text { Has the actual equipment/process successfully } \\
\text { operated in the relevant operational } \\
\text { environment (cold commissioning)? }\end{array}$ & No & \\
\hline TRL 6 & $\begin{array}{l}\text { Has prototypical engineering scale } \\
\text { equipment/process testing been demonstrated } \\
\text { in a relevant environment; to include testing } \\
\text { of the safety function? }\end{array}$ & No & \\
\hline TRL 5 & $\begin{array}{l}\text { Has bench-scale equipment/process testing } \\
\text { been demonstrated in a relevant environment? }\end{array}$ & No & \\
\hline TRL 4 & $\begin{array}{l}\text { Has laboratory-scale testing of similar } \\
\text { equipment systems been completed in a } \\
\text { simulated environment? }\end{array}$ & No & \\
\hline TRL 3 & $\begin{array}{l}\text { Has equipment and process analysis and proof } \\
\text { of concept been demonstrated in a simulated } \\
\text { environment? }\end{array}$ & Yes & $\begin{array}{l}\text { Testing has demonstrated the LiHT process } \\
\text { produces solids that can be readily filtered under } \\
\text { normal laboratory conditions. }\end{array}$ \\
\hline TRL 2 & $\begin{array}{l}\text { Has an equipment and process concept been } \\
\text { formulated? }\end{array}$ & Yes & \\
\hline TRL 1 & $\begin{array}{l}\text { Have the basic process technology process } \\
\text { principles been observed and reported? }\end{array}$ & Yes & \\
\hline
\end{tabular}


Table B.6: Evaluation of TRL 3 Questions for CTE 3

\begin{tabular}{|c|c|c|c|c|}
\hline \multicolumn{5}{|c|}{ TRL 3 Questions for CTE 3 - Filtering of Precipitated LiHT Solids } \\
\hline $\mathrm{T} / \mathrm{P} / \mathrm{M}$ & $\mathbf{Y} / \mathbf{N}$ & & Criteria & Basis and Supporting Documentation \\
\hline $\mathrm{T}$ & $\mathrm{Y}$ & (1) & Academic (basic science) environment & $\begin{array}{l}\text { Basic science and the LiHT process including the } \\
\text { filtering of precipitated LiHT solids are described in } \\
\text { RPP- } 48377, \text { RPP- } 43328, \text { RPP-RPT- } 48380 \text {, } \\
\text { RPP-PLAN-48085, RPP-48376; and "Report on } \\
\text { Qualitative Validation Experiments Using Lithium- } \\
\text { Aluminum Layer Double-Hydroxides for the Reduction } \\
\text { of Aluminum from the Waste Treatment Plant } \\
\text { Feedstock." } \\
\text { Lab-scale testing has demonstrated the LiHT process } \\
\text { produces solids that can be readily filtered under } \\
\text { normal laboratory conditions. }\end{array}$ \\
\hline $\mathrm{P}$ & $\mathrm{Y}$ & (2) & $\begin{array}{l}\text { Some key process and safety } \\
\text { requirements are identified }\end{array}$ & $\begin{array}{l}\text { Key process requirements are identified in } \\
\text { RPP- } 48377 \text { and RPP-PLAN- } 48088 \text {. The process } \\
\text { requirements for TRL } 3 \text { testing of filtering are } \\
\text { identified in the individual steps of the LiHT process } \\
\text { design. } \\
\text { Safety requirements are identified in } \\
\text { RPP-PLAN-48381. }\end{array}$ \\
\hline $\mathrm{T}$ & $\mathrm{Y}$ & (3) & $\begin{array}{l}\text { Predictions of elements of technology } \\
\text { capability validated by analytical studies }\end{array}$ & $\begin{array}{l}\text { Predictions of the filtering capability are provided in } \\
\text { RPP- } 48377 \text { and RPP-PLAN-48088 and validated by } \\
\text { testing documented in RPP-RPT- } 48380 \text {, RPP- } 48376 \text {, } \\
\text { and "Report on Qualitative Validation Experiments } \\
\text { Using Lithium-Aluminum Layer Double-Hydroxides } \\
\text { for the Reduction of Aluminum from the Waste } \\
\text { Treatment Plant Feedstock." }\end{array}$ \\
\hline $\mathrm{P}$ & $\mathrm{Y}$ & (4) & $\begin{array}{l}\text { The basic science has been validated at } \\
\text { the laboratory scale }\end{array}$ & See (3). \\
\hline $\mathrm{T}$ & $\mathrm{Y}$ & (5) & $\begin{array}{l}\text { Science known to extent that } \\
\text { mathematical and/or computer models } \\
\text { and simulations are possible }\end{array}$ & $\begin{array}{l}\text { Filtering is widely practiced in commercial and lab } \\
\text { operations and is easily modeled and simulated. }\end{array}$ \\
\hline $\mathrm{P}$ & $\mathrm{N} / \mathrm{A}$ & (6) & $\begin{array}{l}\text { Preliminary system performance } \\
\text { characteristics and measures have been } \\
\text { identified and estimated }\end{array}$ & Not part of the scope of this TRE. \\
\hline $\mathrm{T}$ & $\mathrm{Y}$ & (7) & $\begin{array}{l}\text { Predictions of elements of technology } \\
\text { capability validated by Modeling and } \\
\text { Simulation (M\&S) }\end{array}$ & See (2) and (5) \\
\hline M & $\mathrm{Y}$ & (8) & $\begin{array}{l}\text { No system components, just basic } \\
\text { laboratory research equipment to verify } \\
\text { physical principles }\end{array}$ & $\begin{array}{l}\text { See (2). } \\
\text { The LiHT Block Diagram and Process Flowsheets } \\
\text { show the conceptual design of the filtering process and } \\
\text { the system components. }\end{array}$ \\
\hline $\mathrm{T}$ & $\mathrm{Y}$ & (9) & $\begin{array}{l}\text { Laboratory experiments verify feasibility } \\
\text { of application }\end{array}$ & See (5) and (8) \\
\hline $\mathrm{T}$ & $\mathrm{Y}$ & (10) & $\begin{array}{l}\text { Predictions of elements of technology } \\
\text { capability validated by laboratory } \\
\text { experiments }\end{array}$ & See (5) and (8) \\
\hline
\end{tabular}


RPP-48379, Rev. 0

\begin{tabular}{|c|c|c|c|}
\hline \multicolumn{4}{|c|}{ TRL 3 Questions for CTE 3 - Filtering of Precipitated LiHT Solids } \\
\hline $\mathrm{T} / \mathrm{P} / \mathrm{M}$ & $\mathbf{Y} / \mathbf{N}$ & Criteria & Basis and Supporting Documentation \\
\hline $\mathrm{P}$ & N/A & $\begin{array}{l}\text { (11) Customer representative identified to } \\
\text { work with development team }\end{array}$ & Not part of the scope of this TRE. \\
\hline $\mathrm{P}$ & N/A & $\begin{array}{l}\text { (12) Customer participates in requirements } \\
\text { generation }\end{array}$ & Not part of the scope of this TRE. \\
\hline $\mathrm{T}$ & $\mathrm{Y}$ & $\begin{array}{l}\text { (13) Requirements tracking system defined to } \\
\text { management requirements creep }\end{array}$ & $\begin{array}{l}\text { Requirements will be tracked with the Technology } \\
\text { Maturation Plan. }\end{array}$ \\
\hline $\mathrm{T}$ & $\mathrm{Y}$ & $\begin{array}{l}\text { (14) Key process parameters/variables and } \\
\text { associated hazards have begun to be } \\
\text { identified. }\end{array}$ & $\begin{array}{l}\text { Key process parameters/variables and associated } \\
\text { hazards are identified in RPP-48377, RPP- } 43328 \text {, } \\
\text { RPP-48376, RPP-48089, RPP-PLAN-48090; and } \\
\text { RPP-PLAN-48091. }\end{array}$ \\
\hline M & $\mathrm{Y}$ & $\begin{array}{l}\text { (15) Design techniques have been } \\
\text { identified/developed }\end{array}$ & See $(2),(5)$ and $(8)$ \\
\hline $\mathrm{T}$ & $\mathrm{Y}$ & $\begin{array}{l}\text { (16) Paper studies indicate that system } \\
\text { components ought to work together }\end{array}$ & See $(2),(5)$, and (8). \\
\hline $\mathrm{P}$ & N/A & (17) Customer identifies technology need date & Not part of the scope of this TRE. \\
\hline $\mathrm{T}$ & $\mathrm{Y}$ & $\begin{array}{l}\text { (18) Performance metrics for the system are } \\
\text { established (What must it do?) }\end{array}$ & $\begin{array}{l}\text { Process yields and cesium decontamination factor after } \\
\text { treating the filtered LiHT precipitate are documented } \\
\text { in RPP-PLAN- } 48088 \text { and RPP- } 48376 \text {. }\end{array}$ \\
\hline $\mathrm{P}$ & N/A & (19) Scaling studies have been started & Not part of the scope of this TRE. \\
\hline M & $\mathrm{Y}$ & $\begin{array}{l}\text { (20) Current manufacturability concepts } \\
\text { assessed }\end{array}$ & See $(2),(5)$ and $(8)$ \\
\hline M & $\mathrm{Y}$ & $\begin{array}{l}\text { (21) Sources of key components for } \\
\text { laboratory testing identified }\end{array}$ & See (2), (5) and (8) \\
\hline $\mathrm{T}$ & $\mathrm{Y}$ & (22) Scientific feasibility fully demonstrated & See $(2),(5)$ and $(8)$ \\
\hline $\mathrm{T}$ & $\mathrm{Y}$ & $\begin{array}{l}\text { (23) Analysis of present state of the art shows } \\
\text { that technology fills a need }\end{array}$ & $\begin{array}{l}\text { TRL-3 testing documented in RPP-RPT- } 48380 \text { has } \\
\text { shown the LiHT process will fill Hanford site waste } \\
\text { treatment technology needs identified in } \\
\text { RPP-PLAN- } 48088 \text {. } \\
\text { The LiHT process will reduce the amount of sodium in } \\
\text { the form of NaOH needed to dissolve Hanford DST } \\
\text { and SST waste aluminum, decrease the WTP } \\
\text { processing time and operational cost, and decrease the } \\
\text { volumes of ILAW glass produced for storage and } \\
\text { disposal. }\end{array}$ \\
\hline $\mathrm{P}$ & N/A & (24) Risk areas identified in general terms & $\begin{array}{l}\text { Not part of the scope of this TRE. Technical risk } \\
\text { briefly discussed in Section } 5.2 \text {. }\end{array}$ \\
\hline $\mathrm{P}$ & N/A & (25) Risk mitigation strategies identified & $\begin{array}{l}\text { Not part of the scope of this TRE. Technical risk } \\
\text { briefly discussed in Section 5.2. }\end{array}$ \\
\hline $\mathrm{P}$ & N/A & $\begin{array}{l}\text { (26) Rudimentary best value analysis } \\
\text { performed for operations }\end{array}$ & Not part of the scope of this TRE. \\
\hline
\end{tabular}


RPP-48379, Rev. 0

\begin{tabular}{|c|c|c|l|}
\hline \multicolumn{5}{|c|}{ TRL 3 Questions for CTE 3- Filtering of Precipitated LiHT Solids } \\
\hline T/P/M & Y/N & \multicolumn{1}{|c|}{ Criteria } & \multicolumn{1}{c|}{ Basis and Supporting Documentation } \\
\hline $\mathrm{T}$ & $\mathrm{Y}$ & $\begin{array}{c}\text { (27) Key physical and chemical properties } \\
\text { have been characterized for a number of } \\
\text { waste samples }\end{array}$ & $\begin{array}{l}\text { Thermochemical data were used in the Environmental } \\
\text { Simulation Program (ESP) to simulate the LiHT } \\
\text { process. }\end{array}$ \\
\hline $\mathrm{T}$ & $\mathrm{Y}$ & $\begin{array}{c}\text { (28) A simulant has been developed that } \\
\text { approximates key waste properties } \\
\text { SST wastes are documented in PNNL-11450. }\end{array}$ & $\begin{array}{l}\text { Development of simulant(s) to approximate key waste } \\
\text { properties is documented in RPP-48377, RPP-48089, } \\
\text { RPP-PLAN-48090; and RPP-PLAN-48091. }\end{array}$ \\
\hline $\mathrm{T}$ & $\mathrm{Y}$ & $\begin{array}{c}\text { (29) Laboratory scale tests on a simulant have } \\
\text { been completed }\end{array}$ & $\begin{array}{l}\text { Independent lab-scale tests of the Georgia Tech } \\
\text { experiments were completed on Hanford DST and SST } \\
\text { simulants by AREVA as described in RPP-43328. }\end{array}$ \\
\hline $\mathrm{T}$ & $\mathrm{Y}$ & $\begin{array}{c}\text { (30) Specific waste(s) and waste site(s) has } \\
\text { (have) been defined }\end{array}$ & $\begin{array}{l}\text { The LiHT process will be used for treatment of } \\
\text { Hanford SST and DST wastes by Hanford WTP at } \\
\text { facilities now under construction. }\end{array}$ \\
\hline $\mathrm{T}$ & $\mathrm{Y}$ & $\begin{array}{c}\text { (31) The individual system components have } \\
\text { been tested at the laboratory scale }\end{array}$ & \begin{tabular}{l} 
See (2), (5), and (8) \\
\hline
\end{tabular} \\
\hline
\end{tabular}


Table B.7: Top-Level Evaluation of TRL for CTE 4

Decontamination of LiHT Solids

\begin{tabular}{|c|c|c|c|}
\hline \multicolumn{2}{|r|}{ Top-Level Questions } & Yes/No & $\begin{array}{l}\text { If Yes, Then } \\
\text { Basis and Supporting Documentation }\end{array}$ \\
\hline TRL 9 & $\begin{array}{l}\text { Has the actual equipment/process successfully } \\
\text { operated in the full operational environment } \\
\text { (hot operations)? }\end{array}$ & No & \\
\hline TRL 8 & $\begin{array}{l}\text { Has the actual equipment/process successfully } \\
\text { operated in a limited operational environment } \\
\text { (hot commissioning)? }\end{array}$ & No & \\
\hline TRL 7 & $\begin{array}{l}\text { Has the actual equipment/process successfully } \\
\text { operated in the relevant operational } \\
\text { environment (cold commissioning)? }\end{array}$ & No & \\
\hline TRL 6 & $\begin{array}{l}\text { Has prototypical engineering scale } \\
\text { equipment/process testing been demonstrated } \\
\text { in a relevant environment; to include testing } \\
\text { of the safety function? }\end{array}$ & No & \\
\hline TRL 5 & $\begin{array}{l}\text { Has bench-scale equipment/process testing } \\
\text { been demonstrated in a relevant environment? }\end{array}$ & No & \\
\hline TRL 4 & $\begin{array}{l}\text { Has laboratory-scale testing of similar } \\
\text { equipment systems been completed in a } \\
\text { simulated environment? }\end{array}$ & No & \\
\hline TRL 3 & $\begin{array}{l}\text { Has equipment and process analysis and proof } \\
\text { of concept been demonstrated in a simulated } \\
\text { environment? }\end{array}$ & Yes & $\begin{array}{l}\text { Testing has demonstrated the LiHT process } \\
\text { generates solids that can be washed sufficiently } \\
\text { to retain less than } 10 \% \text { of the sodium and } \\
\text { cesium. }\end{array}$ \\
\hline TRL 2 & $\begin{array}{l}\text { Has an equipment and process concept been } \\
\text { formulated? }\end{array}$ & Yes & \\
\hline TRL 1 & $\begin{array}{l}\text { Have the basic process technology process } \\
\text { principles been observed and reported? }\end{array}$ & Yes & \\
\hline
\end{tabular}


Table B.8: Evaluation of TRL 3 Questions for CTE 4

\begin{tabular}{|c|c|c|c|c|}
\hline \multicolumn{5}{|c|}{ TRL 3 Questions for CTE 4 - Decontamination of LiHT Solids } \\
\hline T/P/M & $\mathbf{Y} / \mathbf{N}$ & & Criteria & Basis and Supporting Documentation \\
\hline $\mathrm{T}$ & $\mathrm{Y}$ & (1) & Academic (basic science) environment & $\begin{array}{l}\text { Basic science and the LiHT process including the } \\
\text { decontamination of LiHT solids are described in RPP- } \\
48377, \text { RPP- } 43328 \text {, RPP-RPT- } 48380 \text {, } \\
\text { RPP-PLAN-48085, RPP- } 48376 \text {; and "Report on } \\
\text { Qualitative Validation Experiments Using Lithium- } \\
\text { Aluminum Layer Double-Hydroxides for the Reduction } \\
\text { of Aluminum from the Waste Treatment Plant } \\
\text { Feedstock." } \\
\text { Lab-scale testing has demonstrated the LiHT process } \\
\text { generates solids that can be washed sufficiently to } \\
\text { retain less than } 10 \% \text { of the sodium and cesium. }\end{array}$ \\
\hline $\mathrm{P}$ & $\mathrm{Y}$ & (2) & $\begin{array}{l}\text { Some key process and safety } \\
\text { requirements are identified }\end{array}$ & $\begin{array}{l}\text { Key process requirements are identified in } \\
\text { RPP- } 48377 \text { and RPP-PLAN- } 48088 \text {. The process } \\
\text { requirements for TRL } 3 \text { testing of decontamination are } \\
\text { identified in the individual steps of the LiHT process } \\
\text { design. } \\
\text { Safety requirements are identified in } \\
\text { RPP-PLAN- } 48381 \text {. }\end{array}$ \\
\hline $\mathrm{T}$ & $\mathrm{Y}$ & (3) & $\begin{array}{l}\text { Predictions of elements of technology } \\
\text { capability validated by analytical studies }\end{array}$ & $\begin{array}{l}\text { Predictions of the decontamination capability are } \\
\text { provided in RPP- } 48377 \text { and RPP-PLAN- } 48088 \text { and } \\
\text { validated by testing documented in RPP-RPT- } 48380 \text {, } \\
\text { RPP- } 48376 \text {, and "Report on Qualitative Validation } \\
\text { Experiments Using Lithium-Aluminum Layer Double- } \\
\text { Hydroxides for the Reduction of Aluminum from the } \\
\text { Waste Treatment Plant Feedstock." }\end{array}$ \\
\hline $\mathrm{P}$ & $\mathrm{Y}$ & (4) & $\begin{array}{l}\text { The basic science has been validated at } \\
\text { the laboratory scale }\end{array}$ & See (3). \\
\hline $\mathrm{T}$ & $\mathrm{Y}$ & (5) & $\begin{array}{l}\text { Science known to extent that } \\
\text { mathematical and/or computer models } \\
\text { and simulations are possible }\end{array}$ & $\begin{array}{l}\text { Decontamination is widely practiced in commercial } \\
\text { and lab operations and is easily modeled and } \\
\text { simulated. }\end{array}$ \\
\hline $\mathrm{P}$ & N/A & (6) & $\begin{array}{l}\text { Preliminary system performance } \\
\text { characteristics and measures have been } \\
\text { identified and estimated }\end{array}$ & Not part of the scope of this TRE. \\
\hline $\mathrm{T}$ & $\mathrm{Y}$ & (7) & $\begin{array}{l}\text { Predictions of elements of technology } \\
\text { capability validated by Modeling and } \\
\text { Simulation (M\&S) }\end{array}$ & See (2) and (5) \\
\hline M & $\mathrm{Y}$ & (8) & $\begin{array}{l}\text { No system components, just basic } \\
\text { laboratory research equipment to verify } \\
\text { physical principles }\end{array}$ & $\begin{array}{l}\text { See (2). } \\
\text { The LiHT Block Diagram and Process Flowsheets } \\
\text { show the conceptual design of the decontamination } \\
\text { process and the system components. }\end{array}$ \\
\hline $\mathrm{T}$ & $\mathrm{Y}$ & (9) & $\begin{array}{l}\text { Laboratory experiments verify feasibility } \\
\text { of application }\end{array}$ & See (5) and (8) \\
\hline $\mathrm{T}$ & $\mathrm{Y}$ & & $\begin{array}{l}\text { Predictions of elements of technology } \\
\text { capability validated by laboratory } \\
\text { experiments }\end{array}$ & See (5) and (8) \\
\hline
\end{tabular}


RPP-48379, Rev. 0

\begin{tabular}{|c|c|c|c|}
\hline \multicolumn{4}{|c|}{ TRL 3 Questions for CTE 4 - Decontamination of LiHT Solids } \\
\hline $\mathrm{T} / \mathrm{P} / \mathrm{M}$ & $\mathbf{Y} / \mathbf{N}$ & Criteria & Basis and Supporting Documentation \\
\hline $\mathrm{P}$ & N/A & $\begin{array}{l}\text { (11) Customer representative identified to } \\
\text { work with development team }\end{array}$ & Not part of the scope of this TRE. \\
\hline $\mathrm{P}$ & N/A & $\begin{array}{l}\text { (12) Customer participates in requirements } \\
\text { generation }\end{array}$ & Not part of the scope of this TRE. \\
\hline $\mathrm{T}$ & $\mathrm{Y}$ & $\begin{array}{l}\text { (13) Requirements tracking system defined to } \\
\text { management requirements creep }\end{array}$ & $\begin{array}{l}\text { Requirements will be tracked with the Technology } \\
\text { Maturation Plan. }\end{array}$ \\
\hline $\mathrm{T}$ & $\mathrm{Y}$ & $\begin{array}{l}\text { (14) Key process parameters/variables and } \\
\text { associated hazards have begun to be } \\
\text { identified. }\end{array}$ & $\begin{array}{l}\text { Key process parameters/variables and associated } \\
\text { hazards are identified in RPP-48377, RPP- } 43328 \text {, } \\
\text { RPP-48376, RPP-48089, RPP-PLAN-48090, and } \\
\text { RPP-PLAN-48091. }\end{array}$ \\
\hline M & $\mathrm{Y}$ & $\begin{array}{l}\text { (15) Design techniques have been } \\
\text { identified/developed }\end{array}$ & See $(2),(5)$ and $(8)$ \\
\hline $\mathrm{T}$ & $\mathrm{Y}$ & $\begin{array}{l}\text { (16) Paper studies indicate that system } \\
\text { components ought to work together }\end{array}$ & See $(2),(5)$, and (8). \\
\hline $\mathrm{P}$ & $\mathrm{N} / \mathrm{A}$ & (17) Customer identifies technology need date & Not part of the scope of this TRE. \\
\hline $\mathrm{T}$ & $\mathrm{Y}$ & $\begin{array}{l}\text { (18) Performance metrics for the system are } \\
\text { established (What must it do?) }\end{array}$ & $\begin{array}{l}\text { Process yields and cesium decontamination factor after } \\
\text { treating the filtered LiHT precipitate are documented } \\
\text { in RPP-PLAN- } 48088 \text { and RPP- } 48376 \text {. }\end{array}$ \\
\hline $\mathrm{P}$ & $\mathrm{N} / \mathrm{A}$ & (19) Scaling studies have been started & Not part of the scope of this TRE. \\
\hline M & $\mathrm{Y}$ & $\begin{array}{l}\text { (20) Current manufacturability concepts } \\
\text { assessed }\end{array}$ & See $(2),(5)$ and $(8)$ \\
\hline M & $\mathrm{Y}$ & $\begin{array}{l}\text { (21) Sources of key components for } \\
\text { laboratory testing identified }\end{array}$ & See (2), (5) and (8) \\
\hline $\mathrm{T}$ & $\mathrm{Y}$ & (22) Scientific feasibility fully demonstrated & See $(2),(5)$ and $(8)$ \\
\hline $\mathrm{T}$ & $\mathrm{Y}$ & $\begin{array}{l}\text { (23) Analysis of present state of the art shows } \\
\text { that technology fills a need }\end{array}$ & $\begin{array}{l}\text { TRL-3 testing documented in RPP-RPT- } 48380 \text { has } \\
\text { shown the LiHT process will fill Hanford site waste } \\
\text { treatment technology needs identified in } \\
\text { RPP-PLAN- } 48088 \text {. } \\
\text { The LiHT process will reduce the amount of sodium in } \\
\text { the form of NaOH needed to dissolve Hanford DST } \\
\text { and SST waste aluminum, decrease the WTP } \\
\text { processing time and operational cost, and decrease the } \\
\text { volumes of ILAW glass produced for storage and } \\
\text { disposal. }\end{array}$ \\
\hline $\mathrm{P}$ & N/A & (24) Risk areas identified in general terms & $\begin{array}{l}\text { Not part of the scope of this TRE. Technical risk } \\
\text { briefly discussed in Section } 5.2 \text {. }\end{array}$ \\
\hline $\mathrm{P}$ & $\mathrm{N} / \mathrm{A}$ & (25) Risk mitigation strategies identified & $\begin{array}{l}\text { Not part of the scope of this TRE. Technical risk } \\
\text { briefly discussed in Section 5.2. }\end{array}$ \\
\hline $\mathrm{P}$ & $\mathrm{N} / \mathrm{A}$ & $\begin{array}{l}\text { (26) Rudimentary best value analysis } \\
\text { performed for operations }\end{array}$ & Not part of the scope of this TRE. \\
\hline
\end{tabular}


RPP-48379, Rev. 0

\begin{tabular}{|c|c|c|l|}
\hline \multicolumn{4}{|c|}{ TRL 3 Questions for CTE 4-Decontamination of LiHT Solids } \\
\hline T/P/M & Y/N & \multicolumn{1}{|c|}{ Criteria } & \multicolumn{1}{c|}{ Basis and Supporting Documentation } \\
\hline $\mathrm{T}$ & $\mathrm{Y}$ & $\begin{array}{c}\text { (27) Key physical and chemical properties } \\
\text { have been characterized for a number of } \\
\text { waste samples }\end{array}$ & $\begin{array}{l}\text { Thermochemical data were used in the Environmental } \\
\text { Simulation Program (ESP) to simulate the LiHT } \\
\text { process. }\end{array}$ \\
\hline $\mathrm{T}$ & $\mathrm{Y}$ & $\begin{array}{c}\text { (28) A simulant has been developed that } \\
\text { approximates key waste properties } \\
\text { SST wastes are documented in PNNL-11450. }\end{array}$ & $\begin{array}{l}\text { Development of simulant(s) to approximate key waste } \\
\text { properties is documented in RPP-48377, RPP-48089, } \\
\text { RPP-PLAN-48090, and RPP-PLAN-48091. }\end{array}$ \\
\hline $\mathrm{T}$ & $\mathrm{Y}$ & $\begin{array}{c}\text { (29) Laboratory scale tests on a simulant have } \\
\text { been completed }\end{array}$ & $\begin{array}{l}\text { Independent lab-scale tests of the Georgia Tech } \\
\text { experiments were completed on Hanford DST and SST } \\
\text { simulants by AREVA as described in RPP-43328. }\end{array}$ \\
\hline $\mathrm{T}$ & $\mathrm{Y}$ & $\begin{array}{c}\text { (30) Specific waste(s) and waste site(s) has } \\
\text { (have) been defined }\end{array}$ & $\begin{array}{l}\text { The LiHT process will be used for treatment of } \\
\text { Hanford SST and DST wastes by Hanford WTP at } \\
\text { facilities now under construction. }\end{array}$ \\
\hline $\mathrm{T}$ & $\mathrm{Y}$ & $\begin{array}{c}\text { (31) The individual system components have } \\
\text { been tested at the laboratory scale }\end{array}$ & \begin{tabular}{l} 
See (2), (5), and (8) \\
\hline
\end{tabular} \\
\hline
\end{tabular}


Table B.9: Top-Level Evaluation of TRL for CTE 5

Sodium Hydroxide Production

\begin{tabular}{|c|c|c|c|}
\hline \multicolumn{2}{|r|}{ Top-Level Questions } & Yes/No & If Yes, Then \\
\hline TRL 9 & $\begin{array}{l}\text { Has the actual equipment/process successfully } \\
\text { operated in the full operational environment } \\
\text { (hot operations)? }\end{array}$ & No & \\
\hline TRL 8 & $\begin{array}{l}\text { Has the actual equipment/process successfully } \\
\text { operated in a limited operational environment } \\
\text { (hot commissioning)? }\end{array}$ & No & \\
\hline TRL 7 & $\begin{array}{l}\text { Has the actual equipment/process successfully } \\
\text { operated in the relevant operational } \\
\text { environment (cold commissioning)? }\end{array}$ & No & \\
\hline TRL 6 & $\begin{array}{l}\text { Has prototypical engineering scale } \\
\text { equipment/process testing been demonstrated } \\
\text { in a relevant environment; to include testing } \\
\text { of the safety function? }\end{array}$ & No & \\
\hline TRL 5 & $\begin{array}{l}\text { Has bench-scale equipment/process testing } \\
\text { been demonstrated in a relevant environment? }\end{array}$ & No & \\
\hline TRL 4 & $\begin{array}{l}\text { Has laboratory-scale testing of similar } \\
\text { equipment systems been completed in a } \\
\text { simulated environment? }\end{array}$ & No & \\
\hline TRL 3 & $\begin{array}{l}\text { Has equipment and process analysis and proof } \\
\text { of concept been demonstrated in a simulated } \\
\text { environment? }\end{array}$ & Yes & $\begin{array}{l}\text { Testing has demonstrated that the LiHT process } \\
\text { can generate } \mathrm{NaOH} \text {. }\end{array}$ \\
\hline TRL 2 & $\begin{array}{l}\text { Has an equipment and process concept been } \\
\text { formulated? }\end{array}$ & Yes & \\
\hline TRL 1 & $\begin{array}{l}\text { Have the basic process technology process } \\
\text { principles been observed and reported? }\end{array}$ & Yes & \\
\hline
\end{tabular}


Table B.10: Evaluation of TRL 3 Questions for CTE 5

\begin{tabular}{|c|c|c|c|c|}
\hline \multicolumn{5}{|c|}{ TRL 3 Questions for CTE 5 - Sodium Hydroxide Production } \\
\hline T/P/M & $\mathbf{Y} / \mathbf{N}$ & & Criteria & Basis and Supporting Documentation \\
\hline $\mathrm{T}$ & $\mathrm{Y}$ & (1) & Academic (basic science) environment & $\begin{array}{l}\text { Basic science and the LiHT process including the } \\
\text { sodium hydroxide production are described in } \\
\text { RPP- } 48377, \mathrm{RPP}-43328, \mathrm{RPP}-\mathrm{RPT}-48380 \text {, } \\
\text { RPP-PLAN-48085; RPP-48376;and "Report on } \\
\text { Qualitative Validation Experiments Using Lithium- } \\
\text { Aluminum Layer Double-Hydroxides for the Reduction } \\
\text { of Aluminum from the Waste Treatment Plant } \\
\text { Feedstock." } \\
\text { Lab-scale testing has demonstrated that the LiHT } \\
\text { process can generate NaOH. }\end{array}$ \\
\hline $\mathrm{P}$ & $\mathrm{Y}$ & (2) & $\begin{array}{l}\text { Some key process and safety } \\
\text { requirements are identified }\end{array}$ & $\begin{array}{l}\text { Key process requirements are identified in } \\
\text { RPP- } 48377 \text { and RPP-PLAN- } 48088 \text {. The process } \\
\text { requirements for TRL } 3 \text { testing of sodium hydroxide } \\
\text { production are identified in the individual steps of the } \\
\text { LiHT process design. } \\
\text { Safety requirements are identified in } \\
\text { RPP-PLAN- } 488381 \text {. }\end{array}$ \\
\hline $\mathrm{T}$ & $\mathrm{Y}$ & (3) & $\begin{array}{l}\text { Predictions of elements of technology } \\
\text { capability validated by analytical studies }\end{array}$ & $\begin{array}{l}\text { Predictions of the sodium hydroxide production are } \\
\text { provided in RPP- } 48377 \text { and } \\
\text { RPP-PLAN- } 48088 \text { and validated by testing } \\
\text { documented in RPP-RPT- } 48380, \text { RPP- } 48376 \text {, and } \\
\text { "Report on Qualitative Validation Experiments Using } \\
\text { Lithium-Aluminum Layer Double-Hydroxides for the } \\
\text { Reduction of Aluminum from the Waste Treatment } \\
\text { Plant Feedstock." }\end{array}$ \\
\hline $\mathrm{P}$ & $\mathrm{Y}$ & (4) & $\begin{array}{l}\text { The basic science has been validated at } \\
\text { the laboratory scale }\end{array}$ & See (3). \\
\hline $\mathrm{T}$ & $\mathrm{Y}$ & (5) & $\begin{array}{l}\text { Science known to extent that } \\
\text { mathematical and/or computer models } \\
\text { and simulations are possible }\end{array}$ & $\begin{array}{l}\text { Sodium hydroxide production shown in the block flow } \\
\text { diagrams have been modeled in developing the process } \\
\text { design in RPP- } 48377 \text {. }\end{array}$ \\
\hline $\mathrm{P}$ & $\mathrm{Y}$ & (6) & $\begin{array}{l}\text { Preliminary system performance } \\
\text { characteristics and measures have been } \\
\text { identified and estimated }\end{array}$ & See (2) \\
\hline $\mathrm{T}$ & $\mathrm{Y}$ & (7) & $\begin{array}{l}\text { Predictions of elements of technology } \\
\text { capability validated by Modeling and } \\
\text { Simulation (M\&S) }\end{array}$ & See (2) and (5) \\
\hline M & $\mathrm{Y}$ & (8) & $\begin{array}{l}\text { No system components, just basic } \\
\text { laboratory research equipment to verify } \\
\text { physical principles }\end{array}$ & $\begin{array}{l}\text { See (2). } \\
\text { The LiHT Block Diagram and Process Flowsheets } \\
\text { show the conceptual design of the } \mathrm{NaOH} \text { production } \\
\text { process and the system components. }\end{array}$ \\
\hline $\mathrm{T}$ & $\mathrm{Y}$ & (9) & $\begin{array}{l}\text { Laboratory experiments verify feasibility } \\
\text { of application }\end{array}$ & See (5) and (8) \\
\hline $\mathrm{T}$ & Y & & $\begin{array}{l}\text { Predictions of elements of technology } \\
\text { capability validated by laboratory } \\
\text { experiments }\end{array}$ & See (5) and (8) \\
\hline
\end{tabular}


RPP-48379, Rev. 0

\begin{tabular}{|c|c|c|c|}
\hline \multicolumn{4}{|c|}{ TRL 3 Questions for CTE 5 - Sodium Hydroxide Production } \\
\hline $\mathrm{T} / \mathrm{P} / \mathrm{M}$ & $\mathbf{Y} / \mathbf{N}$ & Criteria & Basis and Supporting Documentation \\
\hline $\mathrm{P}$ & N/A & $\begin{array}{l}\text { (11) Customer representative identified to } \\
\text { work with development team }\end{array}$ & Not within the scope of this TRE. \\
\hline $\mathrm{P}$ & N/A & $\begin{array}{l}\text { (12) Customer participates in requirements } \\
\text { generation }\end{array}$ & Not within the scope of this TRE. \\
\hline $\mathrm{T}$ & $\mathrm{Y}$ & $\begin{array}{l}\text { (13) Requirements tracking system defined to } \\
\text { management requirements creep }\end{array}$ & $\begin{array}{l}\text { Requirements will be tracked with the Technology } \\
\text { Maturation Plan. }\end{array}$ \\
\hline $\mathrm{T}$ & Y & $\begin{array}{l}\text { (14) Key process parameters/variables and } \\
\text { associated hazards have begun to be } \\
\text { identified. }\end{array}$ & $\begin{array}{l}\text { Key process parameters/variables and associated } \\
\text { hazards are identified in RPP-48377, RPP- } 43328 \text {, } \\
\text { RPP-48376, RPP-48089, RPP-PLAN-48090, and } \\
\text { RPP-PLAN-48091. }\end{array}$ \\
\hline M & $\mathrm{Y}$ & $\begin{array}{l}\text { (15) Design techniques have been } \\
\text { identified/developed }\end{array}$ & See $(2),(5)$ and $(8)$ \\
\hline $\mathrm{T}$ & $\mathrm{Y}$ & $\begin{array}{l}\text { (16) Paper studies indicate that system } \\
\text { components ought to work together }\end{array}$ & See (2), (5), and (8). \\
\hline $\mathrm{P}$ & N/A & (17) Customer identifies technology need date & Not within the scope of this TRE. \\
\hline $\mathrm{T}$ & $\mathrm{Y}$ & $\begin{array}{l}\text { (18) Performance metrics for the system are } \\
\text { established (What must it do?) }\end{array}$ & $\begin{array}{l}\text { Process yields for } \mathrm{NaOH} \text { production are documented in } \\
\text { RPP-PLAN- } 48088 \text { and RPP- } 48376 \text {. }\end{array}$ \\
\hline $\mathrm{P}$ & N/A & (19) Scaling studies have been started & Not within the scope of this TRE. \\
\hline M & $\mathrm{Y}$ & $\begin{array}{l}\text { (20) Current manufacturability concepts } \\
\text { assessed }\end{array}$ & See $(2),(5)$ and $(8)$ \\
\hline M & $\mathrm{Y}$ & $\begin{array}{l}\text { (21) Sources of key components for } \\
\text { laboratory testing identified }\end{array}$ & See $(2),(5)$ and $(8)$ \\
\hline $\mathrm{T}$ & Y & (22) Scientific feasibility fully demonstrated & See $(2),(5)$ and $(8)$ \\
\hline $\mathrm{T}$ & $\mathrm{Y}$ & $\begin{array}{l}\text { (23) Analysis of present state of the art shows } \\
\text { that technology fills a need }\end{array}$ & $\begin{array}{l}\text { TRL-3 testing documented in RPP-RPT- } 48380 \text { has } \\
\text { shown the LiHT process will fill Hanford site waste } \\
\text { treatment technology needs identified in } \\
\text { RPP-PLAN-48088. } \\
\text { The LiHT process will reduce the amount of sodium in } \\
\text { the form of NaOH needed to dissolve Hanford DST } \\
\text { and SST waste aluminum, decrease the WTP } \\
\text { processing time and operational cost, and decrease the } \\
\text { volumes of ILAW glass produced for storage and } \\
\text { disposal. }\end{array}$ \\
\hline $\mathrm{P}$ & N/A & (24) Risk areas identified in general terms & $\begin{array}{l}\text { Not within the scope of this TRE. Technical risk } \\
\text { briefly discussed in Section } 5.2 \text {. }\end{array}$ \\
\hline $\mathrm{P}$ & N/A & (25) Risk mitigation strategies identified & $\begin{array}{l}\text { Not within the scope of this TRE. Technical risk } \\
\text { briefly discussed in Section } 5.2 \text {. }\end{array}$ \\
\hline $\mathrm{P}$ & N/A & $\begin{array}{l}\text { (26) Rudimentary best value analysis } \\
\text { performed for operations }\end{array}$ & Not within the scope of this TRE. \\
\hline
\end{tabular}


RPP-48379, Rev. 0

TRL 3 Questions for CTE 5 - Sodium Hydroxide Production

\begin{tabular}{|c|c|c|c|}
\hline T/P/M & Y/N & \multicolumn{1}{|c|}{ Criteria } & \multicolumn{1}{c|}{ Basis and Supporting Documentation } \\
\hline $\mathrm{T}$ & $\mathrm{Y}$ & $\begin{array}{l}\text { (27) Key physical and chemical properties } \\
\text { have been characterized for a number of } \\
\text { waste samples }\end{array}$ & $\begin{array}{l}\text { Thermochemical data were used in the Environmental } \\
\text { Simulation Program (ESP) to simulate the LiHT } \\
\text { process. } \\
\text { The composition and quantities of Hanford DST and } \\
\text { SST wastes are documented in PNNL-11450. }\end{array}$ \\
\hline $\mathrm{T}$ & $\mathrm{Y}$ & $\begin{array}{l}\text { (28) A simulant has been developed that } \\
\text { approximates key waste properties }\end{array}$ & $\begin{array}{l}\text { Development of simulant(s) to approximate key waste } \\
\text { properties is documented in RPP-48377, RPP-48089, } \\
\text { RPP-PLAN-48090, and RPP-PLAN-48091. }\end{array}$ \\
\hline $\mathrm{T}$ & $\mathrm{Y}$ & $\begin{array}{l}\text { (29) Laboratory scale tests on a simulant have } \\
\text { been completed }\end{array}$ & $\begin{array}{l}\text { Independent lab-scale tests of the Georgia Tech } \\
\text { experiments were completed on Hanford DST and SST } \\
\text { simulants by AREVA as described in RPP-43328. }\end{array}$ \\
\hline $\mathrm{T}$ & $\mathrm{Y}$ & $\begin{array}{l}\text { (30) Specific waste(s) and waste site(s) has } \\
\text { (have) been defined }\end{array}$ & $\begin{array}{l}\text { The LiHT process will be used for treatment of } \\
\text { Hanford SST and DST wastes by Hanford WTP at } \\
\text { facilities now under construction. }\end{array}$ \\
\hline $\mathrm{T}$ & $\mathrm{Y}$ & $\begin{array}{l}\text { (31) The individual system components have } \\
\text { been tested at the laboratory scale }\end{array}$ & See (2), (5), and (8) \\
\hline
\end{tabular}


Table B.11: Top-Level Evaluation of TRL for CTE 6

Operability of the LiHT Process

\begin{tabular}{|c|c|c|c|}
\hline \multicolumn{2}{|r|}{ Top-Level Questions } & \multirow{2}{*}{$\begin{array}{c}\text { Yes/No } \\
\text { No }\end{array}$} & \multirow{2}{*}{$\begin{array}{l}\text { If Yes, Then } \\
\text { Basis and Supporting Documentation }\end{array}$} \\
\hline TRL 9 & $\begin{array}{l}\text { Has the actual equipment/process successfully } \\
\text { operated in the full operational environment } \\
\text { (hot operations)? }\end{array}$ & & \\
\hline TRL 8 & $\begin{array}{l}\text { Has the actual equipment/process successfully } \\
\text { operated in a limited operational environment } \\
\text { (hot commissioning)? }\end{array}$ & No & \\
\hline TRL 7 & $\begin{array}{l}\text { Has the actual equipment/process successfully } \\
\text { operated in the relevant operational } \\
\text { environment (cold commissioning)? }\end{array}$ & No & \\
\hline TRL 6 & $\begin{array}{l}\text { Has prototypical engineering scale } \\
\text { equipment/process testing been demonstrated } \\
\text { in a relevant environment; to include testing } \\
\text { of the safety function? }\end{array}$ & No & \\
\hline TRL 5 & $\begin{array}{l}\text { Has bench-scale equipment/process testing } \\
\text { been demonstrated in a relevant environment? }\end{array}$ & No & \\
\hline TRL 4 & $\begin{array}{l}\text { Has laboratory-scale testing of similar } \\
\text { equipment systems been completed in a } \\
\text { simulated environment? }\end{array}$ & No & \\
\hline TRL 3 & $\begin{array}{l}\text { Has equipment and process analysis and proof } \\
\text { of concept been demonstrated in a simulated } \\
\text { environment? }\end{array}$ & No & $\begin{array}{l}\text { The current TRL of this CTE was not assessed } \\
\text { because it represents engineering issues that need } \\
\text { to be evaluated in future stages of system design } \\
\text { and development. As the LiHT process matures } \\
\text { and increases in scale, these engineering issues } \\
\text { will be important to the successful operation of a } \\
\text { production scale system. This following } \\
\text { operability issues needs to be evaluated when the } \\
\text { system reaches the appropriate level of maturity: }\end{array}$ \\
\hline TRL 2 & $\begin{array}{l}\text { Has an equipment and process concept been } \\
\text { formulated? }\end{array}$ & No & \\
\hline TRL 1 & $\begin{array}{l}\text { Have the basic process technology process } \\
\text { principles been observed and reported? }\end{array}$ & No & \\
\hline
\end{tabular}


Table B.12: Evaluation of TRL 3 Questions for CTE 6

\begin{tabular}{|c|c|c|c|c|}
\hline \multicolumn{5}{|c|}{ TRL 3 Questions for CTE 6 - Operability of the LiHT Process } \\
\hline $\mathrm{T} / \mathrm{P} / \mathrm{M}$ & $\mathbf{Y} / \mathbf{N}$ & & Criteria & Basis and Supporting Documentation \\
\hline $\mathrm{T}$ & N/A & & Academic (basic science) environment & Beyond the scope of this TRE. \\
\hline $\mathrm{P}$ & N/A & & $\begin{array}{l}\text { Some key process and safety } \\
\text { requirements are identified }\end{array}$ & $\begin{array}{l}\text { For information purposes, the following operability } \\
\text { items, some of which may later become to separate } \\
\text { CTEs, will most likely need to be evaluated for the } \\
\text { pilot-scale system (TRL 6) but are beyond the scope of } \\
\text { this TRE: } \\
\text { (1) Leachate delivery } \\
\text { (2) Sludge and liquid feeds through lines and pumps } \\
\text { (3) Internal and external interfacing } \\
\text { (4) Process control and optimization } \\
\text { (5) Remoteability } \\
\text { (6) Hazards } \\
\text { (7) Safety } \\
\text { (8) Recovery from failure }\end{array}$ \\
\hline $\mathrm{T}$ & $\mathrm{N} / \mathrm{A}$ & (3) & $\begin{array}{l}\text { Predictions of elements of technology } \\
\text { capability validated by analytical studies }\end{array}$ & Beyond the scope of this TRE \\
\hline $\mathrm{P}$ & $\mathrm{N} / \mathrm{A}$ & (4) & $\begin{array}{l}\text { The basic science has been validated at } \\
\text { the laboratory scale }\end{array}$ & Beyond the scope of this TRE \\
\hline $\mathrm{T}$ & $\mathrm{N} / \mathrm{A}$ & (5) & $\begin{array}{l}\text { Science known to extent that } \\
\text { mathematical and/or computer models } \\
\text { and simulations are possible }\end{array}$ & Beyond the scope of this TRE \\
\hline $\mathrm{P}$ & $\mathrm{N} / \mathrm{A}$ & (6) & $\begin{array}{l}\text { Preliminary system performance } \\
\text { characteristics and measures have been } \\
\text { identified and estimated }\end{array}$ & Beyond the scope of this TRE \\
\hline $\mathrm{T}$ & $\mathrm{N} / \mathrm{A}$ & (7) & $\begin{array}{l}\text { Predictions of elements of technology } \\
\text { capability validated by Modeling and } \\
\text { Simulation (M\&S) }\end{array}$ & Beyond the scope of this TRE \\
\hline M & $\mathrm{N} / \mathrm{A}$ & & $\begin{array}{l}\text { No system components, just basic } \\
\text { laboratory research equipment to verify } \\
\text { physical principles }\end{array}$ & Beyond the scope of this TRE \\
\hline $\mathrm{T}$ & $\mathrm{N} / \mathrm{A}$ & & $\begin{array}{l}\text { Laboratory experiments verify feasibility } \\
\text { of application }\end{array}$ & Beyond the scope of this TRE \\
\hline $\mathrm{T}$ & $\mathrm{N} / \mathrm{A}$ & & $\begin{array}{l}\text { Predictions of elements of technology } \\
\text { capability validated by laboratory } \\
\text { experiments }\end{array}$ & Beyond the scope of this TRE \\
\hline $\mathrm{P}$ & $\mathrm{N} / \mathrm{A}$ & & $\begin{array}{l}\text { Customer representative identified to } \\
\text { work with development team }\end{array}$ & Beyond the scope of this TRE \\
\hline $\mathrm{P}$ & N/A & $(12)$ & $\begin{array}{l}\text { Customer participates in requirements } \\
\text { generation }\end{array}$ & Beyond the scope of this TRE \\
\hline
\end{tabular}


RPP-48379, Rev. 0

\begin{tabular}{|c|c|c|c|}
\hline \multicolumn{4}{|c|}{ TRL 3 Questions for CTE 6 - Operability of the LiHT Process } \\
\hline $\mathbf{T} / \mathbf{P} / \mathbf{M}$ & $\mathbf{Y} / \mathbf{N}$ & Criteria & Basis and Supporting Documentation \\
\hline $\mathrm{T}$ & N/A & $\begin{array}{l}\text { (13) Requirements tracking system defined to } \\
\text { management requirements creep }\end{array}$ & Beyond the scope of this TRE \\
\hline $\mathrm{T}$ & N/A & $\begin{array}{l}\text { (14) Key process parameters/variables and } \\
\text { associated hazards have begun to be } \\
\text { identified. }\end{array}$ & Beyond the scope of this TRE \\
\hline M & N/A & $\begin{array}{l}\text { (15) Design techniques have been } \\
\text { identified/developed }\end{array}$ & Beyond the scope of this TRE \\
\hline $\mathrm{T}$ & N/A & $\begin{array}{l}\text { (16) Paper studies indicate that system } \\
\text { components ought to work together }\end{array}$ & Beyond the scope of this TRE \\
\hline $\mathrm{P}$ & N/A & (17) Customer identifies technology need date & Beyond the scope of this TRE \\
\hline $\mathrm{T}$ & N/A & $\begin{array}{l}\text { (18) Performance metrics for the system are } \\
\text { established (What must it do?) }\end{array}$ & Beyond the scope of this TRE \\
\hline $\mathrm{P}$ & N/A & (19) Scaling studies have been started & Beyond the scope of this TRE \\
\hline M & N/A & $\begin{array}{l}\text { (20) Current manufacturability concepts } \\
\text { assessed }\end{array}$ & Beyond the scope of this TRE \\
\hline M & N/A & $\begin{array}{l}\text { (21) Sources of key components for } \\
\text { laboratory testing identified }\end{array}$ & Beyond the scope of this TRE \\
\hline $\mathrm{T}$ & N/A & (22) Scientific feasibility fully demonstrated & Beyond the scope of this TRE \\
\hline $\mathrm{T}$ & N/A & $\begin{array}{l}\text { (23) Analysis of present state of the art shows } \\
\text { that technology fills a need }\end{array}$ & Beyond the scope of this TRE \\
\hline $\mathrm{P}$ & N/A & (24) Risk areas identified in general terms & Beyond the scope of this TRE \\
\hline $\mathrm{P}$ & N/A & (25) Risk mitigation strategies identified & Beyond the scope of this TRE \\
\hline $\mathrm{P}$ & N/A & $\begin{array}{l}\text { (26) Rudimentary best value analysis } \\
\text { performed for operations }\end{array}$ & Beyond the scope of this TRE \\
\hline $\mathrm{T}$ & N/A & $\begin{array}{l}\text { (27) Key physical and chemical properties } \\
\text { have been characterized for a number of } \\
\text { waste samples }\end{array}$ & Beyond the scope of this TRE \\
\hline $\mathrm{T}$ & N/A & $\begin{array}{l}\text { (28) A simulant has been developed that } \\
\text { approximates key waste properties }\end{array}$ & Beyond the scope of this TRE \\
\hline $\mathrm{T}$ & N/A & $\begin{array}{l}\text { (29) Laboratory scale tests on a simulant have } \\
\text { been completed }\end{array}$ & Beyond the scope of this TRE \\
\hline $\mathrm{T}$ & N/A & $\begin{array}{l}\text { (30) Specific waste(s) and waste site(s) has } \\
\text { (have) been defined }\end{array}$ & Beyond the scope of this TRE \\
\hline $\mathrm{T}$ & N/A & $\begin{array}{l}\text { (31) The individual system components have } \\
\text { been tested at the laboratory scale }\end{array}$ & Beyond the scope of this TRE \\
\hline
\end{tabular}

